\title{
Constitutional Precedence and the Genesis of the Belgian Constitution of 1831
}

\author{
Brecht Deseure
}

\section{Contents}

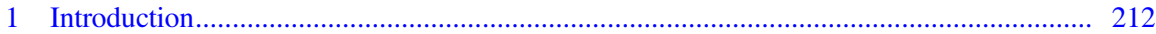

2 From Fundamental Law to Belgian Constitution ........................................................ 214

2.1 The Fundamental Law and the Question of Royal Sovereignty ............................. 214

2.2 'Constitutionals' Versus 'Ministerials': Belgian Constitutional Opposition ............. 220

2.3 Towards a New Legal Order................................................................................. 230

2.4 Constituent Power..................................................................... 236

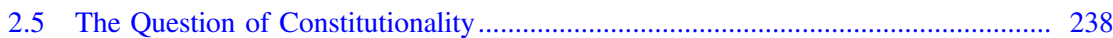

3 Precedence in the Belgian Constitution ....................................................................... 242

3.1 Differentiation from Normal Legislation................................................................... 243

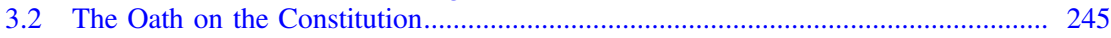

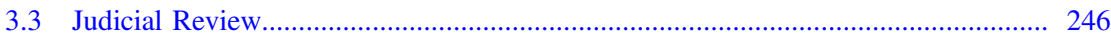

4 Epilogue: Constitutional Discourse After 1831 ........................................................ 248

5 Summary (Dutch): Grondwettelijke Voorrang en het Ontstaan van de Belgische Grondwet van 1831 ............................................................................................ 250

6 Summary (French): La Primauté de La Constitution et La Genèse de La Constitution

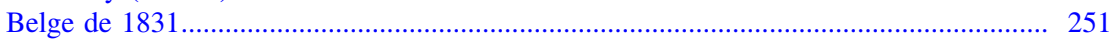

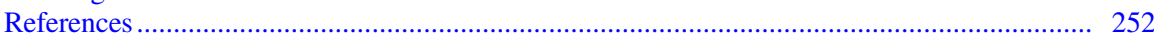

\begin{abstract}
Constitutional precedence constitutes a defining element of modern constitutionalism. This chapter aims to elucidate the way in which this idea was embedded in the Belgian Constitution of 1831. It does so by combining a historical-genealogical approach with a legal one. The chapter begins with a discussion of the genesis of the Belgian Constitution in relation to the Fundamental Law of the United Kingdom of the Netherlands. It shows how the Belgian opposition's constitutional resistance to government policy created a debate over the interpretation of the Fundamental Law, which in turn provided the conceptual building blocks for the understanding of constitutional precedence in the 1831 Constitution. After examining the concept of legal order, the chapter explains how, in the eyes of the
\end{abstract}

B. Deseure $(\bowtie)$

Vrije Universiteit Brussel (VUB), Brussels, Belgium

e-mail: brecht.deseure@vub.ac.be

(C) The Author(s) 2018

U. Müßig (ed.), Reconsidering Constitutional Formation II Decisive Constitutional

Normativity, Studies in the History of Law and Justice 12,

https://doi.org/10.1007/978-3-319-73037-0_5 
Belgian revolutionaries, the Belgian Constitution could be a legitimate replacement for the Fundamental Law as the foundational document of the state. The concern for constitutional precedence was expressed furthermore by recurring debates within the National Congress and the press over the constitutionality of the acts of both the constituting and constituted powers. The chapter then turns to the constitutional text and analyzes the way the precedence of the Constitution was legally anchored into the Belgian state system. Constitutional precedence was expressed by a combination of measures concerning (a) the special status and the endurance of constitutional law as compared to ordinary law and (b) the Constitution's status as the legally binding ground rule for the constituted powers. Finally, the precedence of the Constitution was symbolically expressed by a discourse of respect for the Constitution as the ultimate guarantee of the wellbeing of the state.

\section{Introduction}

In 1852 a lavishly illustrated edition of the Belgian Constitution was published at the behest of Prime Minister Charles Rogier. ${ }^{1}$ It was only one of many government-sponsored initiatives to harness popular support for the Constitution in the years following the eventful year $1848 .{ }^{2}$ In stark contrast to its neighboring countries, the revolutionary wave failed to stir up any serious unrest in Belgium. ${ }^{3}$ The Constitution, the fruit of the Belgian Revolution of 1830, was credited for the young state's remarkable institutional stability. Its liberal character was supposed to have prevented the outburst of a popular revolt. The Constitution was thus celebrated in various forms, including the erection of the Congress Column in Brussel and the publication of the ornate illustrated edition of 1852 .

The 1852 volume opens with an allegory depicting Belgium as a maiden. She wears a city crown and is accompanied by the Belgian lion, which rests its paw on the broken chains of slavery. ${ }^{4}$ Above her head she holds the biblical Tables of the Law inscribed with the words "Constitution de la Belgique 1831". The shield on which she sits is supported by Belgians of various professional classes: a farmer, a soldier, a judge, a militia member and an artisan. Iconological analysis has shown that Belgian and constitutional imagery are inextricably linked in this image, making it hard to separate the one from the other. ${ }^{5}$ And that was undoubtedly the message intended by its creators: indeed the Belgian state and its Constitution were linked to each other to such degree as to make the existence of the one directly dependent on the other. As the reference to the broken chains makes clear, the

\footnotetext{
${ }^{1}$ Brown and Lagye (1852). On Rogier: Discailles (1907).

${ }^{2}$ Huygebaert (2015) and Janssens (2001, p. 52).

${ }^{3}$ Witte (2010).

${ }^{4}$ On the political imagery of the young Belgian state see: Dubois (2005a) and Janssens (2005).

${ }^{5}$ Huygebaert (2015).
} 
Constitution consolidated the achievements of the Belgian Revolution of 1830, which was itself the founding event of the Belgian state. The Constitution thus incarnated the principles on which Belgian independence hinged, and guaranteed their endurance. The maintenance and the defense of the conceptual pair country and Constitution was a task entrusted to the Belgian people, depicted in the lower level. ${ }^{6}$ The image thus expresses both sacred respect for the Constitution and popular support by the Belgian people.

The exceptional position of the Constitution in the Belgian state system was not merely rhetorical. As this chapter aims to show, the symbolic precedence of the Constitution reflected the real, legal precedence it enjoyed in practice. The Constitution in Belgium was not like ordinary law: it was the founding document of the new state, legally anchoring the unalterable rights of the citizens and the division and exercise of power. Thus it constituted the ultimate juridical basis for both the legal and political order of the new state. The members of the National Congress, Belgium's constituent assembly, were acutely aware of the foundational character of the nascent constitutional document, calling it "an arch of alliance" on which the future wellbeing of the state would rest for generations to come. ${ }^{7}$

Precedence of constitution is here defined as the concept of establishing the political and legal order in a positive and uniform legal text which constitutes a prior and binding legal norm. The idea of constitutional precedence, a defining feature of modern constitutionalism, was still relatively new at the time of the Belgian Constitution's genesis. Its main historical competitor and conceptual antithesis, monarchical sovereignty, was ubiquitous in Restoration Europe. ${ }^{8}$ The Belgian Constitution was proclaimed on 7 February 1831 in the name of the Belgian people and in the absence of a ruling monarch. ${ }^{9}$ As this chapter will show, the triumph of the concept of constitutional precedence resulted from the power vacuum created by the Belgian Revolution against Dutch rule. Moreover, the Belgian opposition's resistance against government policy, based on the Fundamental Law of 1815, provided the conceptual building blocks for the understanding of constitutional precedence in the 1831 Constitution.

This chapter will use a genealogical approach to explain the emergence of constitutional precedence in Belgium in 1831. It will first turn to the Fundamental Law of 1815 and the debate over its interpretation, which gave rise to the Belgian constitutional opposition. ${ }^{10}$ After looking at the concept of "legal order", it will explain how the Belgian Constitution could, in the eyes of the Belgian revolutionaries, legitimately replace the Fundamental Law as the foundational document of the state.

\footnotetext{
${ }^{6} \mathrm{Cf}$. Footnote 151.

${ }^{7}$ Huyttens (1844-1845), vol 3, p. 369, 01/07/1831.

${ }^{8}$ Kirsch (1999), Mirkine-Guetzévitch (1831), Müßig (2013) and Prutsch (2013).

${ }^{9}$ Deseure (2016a, p. 12).

${ }^{10}$ See Delbecke's argument in De lange schaduw van de grondwetgever: perswetgeving en persmisdrijven in België (1831-1914), p. 93 that the press legislation in the Belgian Constitution cannot be understood without taking into account the Belgian opposition to the press policy of the Dutch minister Van Maanen.
} 
Secondly, the chapter will turn to the constitutional text, analyzing the way in which the precedence of the Constitution was legally anchored into the Belgian state system.

\section{From Fundamental Law to Belgian Constitution}

\subsection{The Fundamental Law and the Question of Royal Sovereignty}

On 12 October 1830 the Constitutional Commission convened for the first time in Brussels to draw up a Constitution for the new country. ${ }^{11}$ The Provisional Government had created the Commission a few days after declaring Belgian independence from the United Kingdom of the Netherlands. ${ }^{12}$ In just two weeks the Commission produced a draft Constitution which went on to serve as the guiding document for the constituent debates in the National Congress. Most of the basic principles of the final Constitution were already present in this draft. ${ }^{13}$ Knowing that only a few months earlier the idea of Belgian independence was wholly alien to most participants in the political debate, this short span of time may be surprising. ${ }^{14}$ With the exception of the republican journalist Louis de Potter, even the most radical members of the Belgian opposition had not seriously suggested the option of a Belgian secession from the Kingdom of the Netherlands. ${ }^{15}$ Neither did the commissioners have previous experience with constituent work. Nevertheless, they managed to produce a balanced constitutional document containing a clear and consistent vision on the functioning of constitutional monarchy.

This result was only possible because the Commission started its activities after a period in which such issues had been widely discussed. During the fifteen years of its existence, the United Kingdom had seen much political debate on the basic features of the state. Especially in the years 1814-1817 and 1827-1830, the institutions and the Constitution of the Kingdom had been the object of intense discussion. Profound theoretical reflection on the nature and the architecture of constitutional monarchy had been produced. The members of the Constitutional Commission and the National Congress could draw on excellent political treatises such as the ones written on constitutional monarchy and ministerial responsibility by Joseph Lebeau, Jean-François Tielemans and Charles-Hippolyte Vilain XIIII, among others. ${ }^{16}$ In short, both ideological camps within the Belgian opposition,

\footnotetext{
${ }^{11}$ Van den Steene (1963).

${ }^{12}$ Bulletin des arrêtés et actes du Gouvernement Provisoire de la Belgique (1830), no. 5, p. 13, decree of 6 October 1830.

${ }^{13}$ Gilissen (1967, p. 60). The most fundamental difference with the final Constitution concerned the presence of an aristocratic Senate, which gave it a more conservative character.

${ }^{14}$ Aerts (2006) and Witte (2006, p. 59).

${ }^{15}$ Juste (1874).

${ }^{16}$ Lebeau (1830), Tielemans (1829) and Vilain (1830).
} 
Catholics and Liberals, had ample time to develop their political-theoretical views by the time the convention started.

The question of the interpretation of the Constitution had indeed been at the core of the conflict between government and opposition that eventually led to the ad hoc separation of the Kingdom. The experience of debating the Constitution in the face of an ever more autocratic government had provided the Belgian elites with training in political and constitutional matters. ${ }^{17}$ In his opening speech for the National Congress, Louis de Potter spoke of "the arbitrariness of the ministers, which has forced us to advance every day more into a career of constitutional opposition". ${ }^{18}$ Etienne de Gerlache, president of the Congress and member of the Constitutional Commission, called the experience useful for the political education of the Belgians:

(...) despite its exclusive and obtrusive character, the fifteen years of this semi-liberal, semi-absolutist regime proved to be useful for our political education. ${ }^{19}$

When the Belgian Revolution broke out, the ideas developed in the previous years could be put into practice. ${ }^{20}$ One must therefore look to the Fundamental Law and the debates it engendered when trying to understand the genesis of the modern concept of the Constitution in Belgium and its defining characteristic, namely constitutional precedence.

At first sight a constitutional document entitled Fundamental Law seems to relate more to the Ancien Régime than to Restoration constitutionalism. From the sixteenth century on, the leges fundamenales, which could be either written or unwritten, came about as the successors to the medieval state treaties (Herrschaftsverträge) ${ }^{21}$ Although they did constitute general rules of sorts for the government of the early modern kingdoms, these fundamental laws cannot be compared to modern constitutions. Far from constituting a prior set of unified and legally binding rules reflecting an underlying political theory, they were the pragmatic and changeable outcome of politically and historically informed negotiations between monarchs and their subjects.

The name given to the Constitution of the Kingdom of the Netherlands is deceptive however. In the constitutional construction devised by Gijsbert Karel Van Hogendorp (1762-1834), deliberate allusions to continuity with the prerevolutionary past were manifold. Van Hogendorp was the architect of the new Dutch state established after Napoleon's defeat at Leipzig. ${ }^{22}$ His constitutional draft,

\footnotetext{
${ }^{17}$ Witte (2016, p. 43).

18،“(...) des progrès que l'arbitraire ministériel nous forçait chaque jour à faire dans la carrière de l'opposition constitutionnelle". Huyttens (1844-1845), vol. 1, p. 100, 10/11/1830.

${ }^{19}$ “ $(\ldots)$ ce régime de quinze années, semi-libéral, semi-absolu, malgré sa tendance exclusive et envahissante, ne laissa pas d'être utile à notre éducation politique". De Gerlache (1859), vol. 2, p. XXIII.

${ }^{20}$ Marteel (2009, p. 411), Van Sas (1992, p. 434) and Witte (2016, p. 16).

${ }^{21}$ Stourzh (1977, p. 61).

${ }^{22}$ Breukelman (1912) and Slijkerman (2013, pp. 123-192).
} 
written in 1812, served as the blueprint for the Fundamental Law. ${ }^{23}$ His 'Burgundian vision' was based upon an idealized view of the time when the Netherlands had been united under a single sovereign monarch. ${ }^{24}$ The names he introduced for the new institutions reflected that vision: Estates General (for the Parliament), Provincial Estates (for regional assemblies), knighthoods (for the representation of the nobility within the Provincial Estates). The Republic of the United Netherlands' venerable constitutional document, The Union of Utrecht, was not resurrected however. For Van Hogendorp, restoring the 'natural order' of the Burgundian Netherlands entailed bypassing the republican past. ${ }^{25}$

Van Hogendorp's invention of traditions is indicative of his conservatism and of his nostalgia for the prerevolutionary national past. At the same time the references to an idealized past served to conceal what was a modern conception of the Constitution. $^{26}$ The successive constitutional experiments of the Batavian Republic and the Kingdom of Holland, followed by the annexation to the French Empire, had all left their traces on the post-revolutionary constitutional order. ${ }^{27}$ Van Hogendorp intended the Constitution to be a binding basic rule for the state's institutions and the exercise of power. ${ }^{28}$ When Prince William Frederick of Orange-Nassau, the son of the last stadtholder, was invited to take power in Holland in 1813 as 'Sovereign Prince', it was made clear to him that the conditions for his rule were to be laid down in a binding Constitution. ${ }^{29}$ When making his entry into Amsterdam, William himself made his acceptance of the throne conditional on "the guarantees provided by a wise constitution". 30 The Constitution was debated by a Constitutional Commission presided over by Van Hogendorp, and was adopted by an assembly of notables convened in Amsterdam on 29 March 1814. William was inaugurated as Sovereign Prince only after swearing an oath on the Constitution, the next day. At this time there was a clear awareness that the Fundamental Law constituted a binding contract between the monarch and the Nation, which rested on an implicit agreement between both parties. ${ }^{31}$

Sovereignty was not explicitly defined in the Fundamental Law. Van Hogendorp's vision of the Constitution relied, not on abstract theory or universal

\footnotetext{
${ }^{23}$ Colenbrander (1908), vol. 1, pp. 1-14.

${ }^{24}$ Aerts (2006, p. 25), Marteel (2012, p. 38), Slijkerman (2013, p. 157), Tamse and Witte (1992, p. 10), Van Sas (2004a, p. 462), Van Velzen (2005, p. 23), Van Zanten (2004, p. 26), and Worst (1992, p. 58).

${ }^{25}$ Van Velzen (2005, p. 23).

${ }^{26}$ Marteel (2009, p. 27) and Slijkerman (2013, p. 138).

${ }^{27}$ Aerts (2016, p. 47) and Velema (1998).

${ }^{28}$ Slijkerman (2013, pp. 195-196).

${ }^{29}$ Van Sas (1992, p. 179), Van Velzen (2005, p. 57). For a different opinion, see: Bos (2009, p. 86).

${ }^{30}$ Proclamation of the Sovereign Prince, 2 December 1813. Colenbrander (1908), vol. 1, p. 26. See: Koch (2013, p. 233) and Van Sas (2004b).

${ }^{31}$ Van Velzen (2005, p. 422). Koch argues that William considered the Constitution as a mere façade for monarchical government from the very beginning. His influence on the deliberations of the Constitutional Commission has moreover been considerable. Koch (2013, p. 247).
} 
principles, but on the organic order of government based on history and national traditions. ${ }^{32}$ In his view, explicit reflection on political theory could only serve to obscure the right ideas on the exercise of power. It is no coincidence that Van Hogendorp was an admirer of the Enlish model of constitutional monarchy, the principles of which he tried to introduce in the Dutch context. ${ }^{33}$ The result was a model of mixed monarchy. Whereas the monarch was sovereign, his power was limited by an aristocratic and a (very moderately) democratic element. Royal power was not absolute since it was subject to the Constitution, which defined the preliminary rules of the political game for all actors including the King.

The uncertainties of the domestic political situation hardly permitted the monarch to make a bid for absolute sovereignty. When the Dutch regained national independence by shaking off French rule, a new form of state needed to be improvised on the spot. William could not know what was awaiting him on the other side of the Channel when he accepted the Dutch throne. ${ }^{34}$ The domestic situation and the international political context were uncertain. William's inauguration on 30 March 1814 preceded both Waterloo and the Congress of Vienna, marking the final defeat of Napoleonic France and the establishment of a Restoration order based on the monarchical principle respectively.

The consolidation of the Restoration order, from 1815 onward, allowed William to wield monarchical power in a more self-confident manner. ${ }^{35}$ The London Protocol of 21 June 1814 decided on the unification of Belgium and the Netherlands. On $16 \mathrm{March}$ 1815, anticipating the final act of the Vienna Congress, William assumed the title of King of the Netherlands. ${ }^{36}$ When Van Hogendorp lost his place as the King's privileged counselor to Cornelis Felix Van Maanen (1769-1846), a gradual theoretical shift began. ${ }^{37}$ Van Maanen, former Minister of Justice under the Kingdom of Holland and president of the Imperial Court in The Hague, had been a faithful servant of the centralist imperial regime. ${ }^{38}$ His unshakeable belief in the principle of absolute royal authority induced him to develop a concept of monarchical sovereignty that preceded the Constitution. Peter Van Velzen has termed this innovative concept 'preliminary sovereignty'. ${ }^{39}$ According to Van Maanen, the King had already been fully sovereign before the introduction of the Constitution. He had, in fact, freely consented to constitutional limitations on his royal power. ${ }^{40}$ Van Maanen did not go so far as to call the

\footnotetext{
${ }^{32}$ Aerts $(2016,48)$.

${ }^{33}$ Slijkerman (2013, p. 140) and Van Velzen (2005, p. 17).

${ }^{34}$ Koch (2013, p. 226), Lok (2011) and Van Sas (1992, p. 179).

${ }^{35}$ Van Sas (1992, p. 179) and Van Velzen (2005, p. 151).

${ }^{36}$ Colenbrander (1908), vol. 2, pp. 64-65. William had already supplied for the temporary government of Belgium since 1 August 1814 at the request of the allied powers. Rotteveel Mansveld and Velle (2016, p. 9).

${ }^{37}$ Van Velzen (2005, p. 53).

${ }^{38}$ Blok (1914, pp. 803-805).

${ }^{39}$ Van Velzen (2005, pp. 151-173).

${ }^{40}$ Aerts $(2016,52)$.
} 
Constitution a charte octroyée which could be withdrawn at will, since the King had sworn an oath to uphold it. ${ }^{41}$ Nevertheless, he considered the King to be the only source of sovereignty and interpreted the Fundamental Law accordingly.

An increasing tendency towards autocratic and authoritarian government accompanied this theoretical shift. ${ }^{42}$ William did not consider the Nation as a contracting party, but as a passive receiver of royal benefactions. This meant that he systematically increased the royal competences in government using the argument that all the residual powers - those powers not explicitly attributed by the Constitution-were the exclusive competence of the King. ${ }^{43}$ In addition to interpreting the Constitution in a way that allowed for a maximum development of royal power, the government also took legislative initiatives to undermine the checks on royal power prescribed by the Fundamental Law. Parliamentary control over the budget was hollowed out, while the 'Blanket law' of 1818 and the 'Conflict law' of 1822 allowed the King to settle a major part of the decision-making by royal decree. $^{44}$ Indeed, after 1822 , the government rarely consulted Parliament.

The monarchical interpretation of the Fundamental Law defended by Van Maanen relied on a literal reading. Van Hogendorp, who no longer played a role in government, gradually came to contest this reading. ${ }^{45} \mathrm{He}$ argued that it did not conform to the intentions of the Constitutional Commission. He conceded that the absolutist interpretation was facilitated by the lacunas and ambiguous formulations of the constitutional text itself. $^{46}$ Indeed, these weaknesses enhanced the Fundamental Law's failure to effectively limit monarchical power. ${ }^{47}$

The most prominent issue which had not been convincingly resolved was that of ministerial responsibility. The issue touched the very nature of constitutional monarchy, since it was all about the degree to which the government could be held accountable by the representatives of the Nation. Art. 177 of the Fundamental Law of 1815 specified the juridical responsibility of ministers for crimes committed during the exercise of their functions. ${ }^{48}$ The accusation was put forward by the Public Prosecutor (whose appointment was a royal prerogative) before the High Court. Parliament needed to consent to the prosecution of a minister but it could not take the initiative. Peter Van Velzen has shown that both Van Hogendorp and the Belgian members of the Constitutional Commission of 1815 were confused on the exact implications of the article. ${ }^{49}$

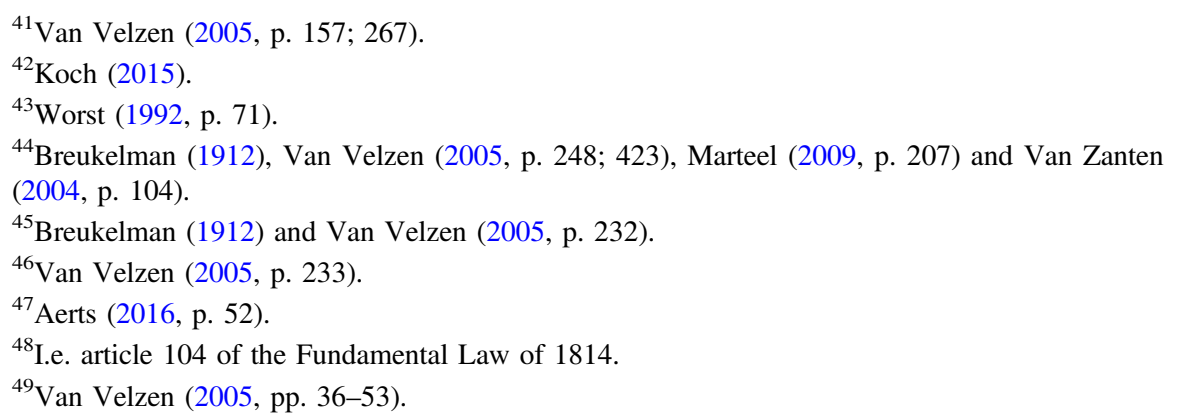


Van Hogendorp had intended the article to allow for parliamentary initiative, so that the juridical responsibility of ministers would automatically result in (individual) political responsibility to Parliament. He also expected the ministers to be liable to prosecution for violating the Constitution. In his view, this was the ideal system of constitutional monarchy, as it had existed in England in the second half of the seventeenth and the first half of the eighteenth century. ${ }^{50}$ It guaranteed strong royal power tempered by respect for the Constitution and a certain degree of parliamentary control. He rejected the principle of royal inviolability however, since that combination threatened to result in parliamentary government and merely symbolic royal power in the long run. On the other hand, he did assume that royal inviolability would develop in practice. ${ }^{51}$

Discussion on these issues was rekindled by the presence of Belgian members in the Constitutional Commission of 1815, which was convened to adapt the Fundamental Law to the new reality of the integration of the Belgian territories. The liberals among them were strongly inspired by the political theory of Benjamin Constant. Objections were raised against the absence of a number of stipulations which they considered essential for a constitutional monarchy, including royal inviolability, ministerial responsibility to Parliament for violations of the Constitution and parliamentary confidence for ministers. ${ }^{52}$ These questions laid bare a fundamental division of opinions between the Northern and Southern members of the Commission. In the ensuing discussions, the Belgians were placated and led to believe that their demands were implied by Art. 177, without explicitly being mentioned in the constitutional text.

The curious confusion over the real implications of Art. 177 had grave consequences for the future of the United Kingdom of the Netherlands. ${ }^{53}$ It set the stage for the fundamental constitutional discussions of the following years, which shook the Kingdom to its foundations. The constitutional uncertainty would contribute to the Belgian opposition against the Dutch government and, eventually, set the agenda for the Belgian constituent debates in 1830. Central to these debates were the issues of the position of the Constitution as prior legal norm for governmental action and, following from it, the accountability of the King's government to Parliament.

\footnotetext{
${ }^{50}$ Van Velzen (2005, pp. 7-19).

${ }^{51}$ Van Velzen (2015, p. 121).

${ }^{52}$ Van Velzen (2005, pp. 36-53).

${ }^{53}$ In 1817 King William tried to come to terms with the opposition by offering to include the parliamentary initiative for the prosecution of ministers in the Constitution. For strategic reasons the opposition refused the offer, and argued that the parliamentary initiative was presupposed by the Constitution. Marteel (2009, p. 209) and Van Velzen (2005, pp. 99-130). For the development of ministerial responsibility in the Netherlands after 1848: Slijkerman (2011).
} 


\section{2 'Constitutionals' Versus 'Ministerials': Belgian Constitutional Opposition}

The introduction of the Fundamental Law in the Belgian part of the Kingdom was controversial from the start. The unification of Belgium and Holland had been decided under the condition of establishing an "intimate and complete amalgam" between both territories. ${ }^{54}$ As mentioned above, the 1814 Fundamental Law was adjusted to the new territorial situation by a Constitutional Commission made up of Dutch and Belgian members. Among the most prominent changes introduced at the behest of the Belgian members was bicameralism. In order to obtain legitimacy for the new Constitution among the Belgians, King William decided to submit it to an assembly of notables, in the absence of a regular body representing the Nation in the Belgian territories. 796 of the 1323 notables who cast their vote rejected the Fundamental Law. ${ }^{55}$ The main reason for the rejection - and of the unpopularity of the Constitution with the Belgian population at large- - was religious. ${ }^{56}$ Unification with the predominantly Protestant North was an unwelcome prospect to many Belgian Catholics. The Belgian bishops, headed by the intransigent archbishop of Mechelen, had openly campaigned against it because of its introduction of the freedom of worship. ${ }^{57}$ The King reacted by changing the outcome of the vote. He decided that abstentions should be counted as approvals, and that protest against the freedom of worship was an invalid reason for rejection, since that principle was one of the conditions imposed by the London Protocol. ${ }^{58}$ Thus, the Fundamental Law was introduced against the opinion of the conservative Belgian elites. The overtly Machiavellian manipulation of the plebiscite led large parts of Belgian public opinion to question the legitimacy of the new Constitution. Even those who agreed with it in principle were critical of the King's actions.

During this period, conservative Catholic thinking was strongly anti-constitutionalist, and harked back to prerevolutionary ancient constitutionalism and Gallicanism. ${ }^{59}$ However, a modern, liberal point of view developed alongside it. This strand of thinking embraced constitutional monarchy and welcomed the prospect of unification. The most important constitutionalist thinker in those years was Pierre-François Van Meenen, editor of the journal L'Observateur politique, administratif, historique et littéraire de la Belgique. ${ }^{60}$ Van Meenen's thorough theoretical analyses of constitutional monarchy influenced a whole generation of Belgian liberals, many of whom would later take

\footnotetext{
${ }^{54}$ Colenbrander (1908), vol. 2, p. 27.

${ }^{55}$ Colenbrander (1908), vol. 2, p. 617.

${ }^{56}$ Gilissen (1958, p. 59) and Marteel (2009, p. 98).

${ }^{57}$ Demoulin (1989) and Marteel (2006, p. 46).

${ }^{58}$ The Protocol had in fact been drawn up by William himself and his Secretary of State Anton Falck. Koch (2013, p. 268).

${ }^{59}$ Marteel (2009, pp. 95-110).

${ }^{60}$ Le Roy (1897), Marteel (2006, p. 49), Van den Steene (1963, pp. 17-19).
} 
part in the Belgian Revolution. ${ }^{61}$ The writings of Benjamin Constant were obviously an inspiration to this group.

Van Meenen and his followers were shocked to find that the Fundamental Law did not allow Parliament to hold the government accountable for its actionsespecially given the absence of parliamentary initiative for the prosecution of ministers. ${ }^{62}$ L'Observateur began a campaign of systematic opposition to the government, lobbying for ministerial responsibility and freedom of the press. In the face of the increasingly autocratic government of William I, this initiative failed to achieve practical results, but it did succeed in laying the theoretical groundwork for the large-scale Belgian opposition of later years.

L'Observateur's last issue appeared in 1820. In the same year the Estates General approved the decennial budget, their only real check on government policy. The opposition did not manage to take a stand in the following years, despite its protest against the Conflict Law of 1822 and the continued postponement of the creation of a High Court for the judgment of ministers. The Estates General were too divided along North-South lines to allow for organized opposition against the government. ${ }^{63}$ Moreover, economic prosperity in the South took away much of the oppositional drive.

The middle of the 1820 s marked a turnabout. In 1815 , political consciousness in Belgium had been relatively limited, a majority of the population remaining indifferent towards politics, but around the middle of the next decade, a new generation of liberal intellectuals entered the scene. These men were mostly born and educated under French or Dutch rule and had no active memories of the Old Regime. ${ }^{64}$ The first sign of the growing political awareness of this group was the foundation of the newspaper Mathieu Laensberg in Liège, which commented critically on political and constitutional issues. ${ }^{65}$ These younger liberals remained strongly under the influence of the older generation who had already embraced modern constitutional theory, especially as formulated by Benjamin Constant. ${ }^{66}$ Around the same time, a fundamental shift, triggered by recent political events, occurred within the Catholic intelligentsia and the Catholic opposition embraced a liberal-constitutional discourse. ${ }^{67}$ Both oppositional movements joined forces in 1827.

From 1828 on, debate between the Belgian opposition and the government flared up, both in the Estates General and in the press. The question of accountability of government was central to the controversy. This issue came to the fore in debates

\footnotetext{
${ }^{61}$ Marteel (2009, p. 49).

${ }^{62}$ Van Velzen (2005, p. 99).

${ }^{63}$ Fear for Belgian domination in the United Kingdom led most Northern members to support the government and to swallow their criticism on governmental and constitutional policy. Van Velzen (2005, p. 200).

${ }^{64}$ Marteel (2009, p. 326).

${ }^{65}$ Harsin (1930, p. 37). For the separate developments in Brussels and Liège: Marteel (2009, p. $281 ; 328)$.

${ }^{66}$ Marteel (2009, p. 327), Marteel (2012, p. 59) and Van Velzen (2015).

${ }^{67}$ Marteel (2009, pp. 265-310).
} 
over ministerial responsibility to Parliament and the freedom of the press, which were strongly related. ${ }^{68}$ The press trials instigated by Minister Van Maanen were a major point of contention. Journals taking a critical stance towards the governments were increasingly being prosecuted for sedition and lese-majesty. The government argued that attacking the government equated to attacking the King, since the King was not inviolable and the minsters were responsible only to him. The newspapers on the other hand argued that the Fundamental Law implied ministerial responsibility to Parliament, much as Van Hogendorp has initially intended. ${ }^{69}$ As a consequence, they considered it legitimate to attack the ministers without harming the King.

These controversies and argumentations have been extensively described elsewhere. What counts for the present chapter is the ubiquitousness of the Fundamental Law in the debates. ${ }^{70}$ Both camps based their arguments on the Constitution, but they interpreted it in a fundamentally different way. By arguing that all their major demands were guaranteed by the Fundamental Law, the opposition tried to show that the King and the government behaved unconstitutionally. Real or supposed provisions of the Fundamental Law were therefore cited time and again, both in Parliament and in the press. ${ }^{71}$ The government reacted by refuting these arguments and promoting an alternative reading of the Constitution.

Whereas the government had previously been reluctant to make explicit statements on constitutional principles, it now actively engaged in the debate. ${ }^{72}$ In the session of the Estates General of 20 December 1827, Minister Van Gobbelschroy defended the gradual increase in royal power by stating that all competences that were not mentioned in the Constitution, were the domain of the King. ${ }^{73}$

In 1828, the oppositional newspaper Courrier des Pays-Bas published a vehement critique on the address from the throne. ${ }^{74}$ It accused the ministers of compromising the monarch by turning him into the mouthpiece for their own faulty interpretation of the Fundamental Law. Instead of recognizing the role of the press as the watchdog of constitutional government, they took all kinds of measures to curb public debate. The newspaper feared for the maintenance of the constitutional liberties, and argued that the address from the throne clearly illustrated "the profound ignorance of the ministerial writers in matters of our constitutional laws and the historical principles from which they emanate". ${ }^{75}$

\footnotetext{
${ }^{68}$ Delbecke (2012, p. 44).

${ }^{69}$ Harsin rejects this interpretation: Harsin (1937, p. 167).

${ }^{70}$ Harsin (1937, p. 174), Van Velzen (2005, p. 422) and Witte (2016, p. 43). This was also true for the political press in the North: Van Sas (2004b, p. 467).

${ }^{71}$ Harsin (1930) and Marteel (2006, p. 46).

${ }^{72}$ Worst (1992, p. 63).

${ }^{73}$ Handelingen Tweede Kamer 1827-1828, pp. 117-119. Van Velzen (2005, p. 270).

${ }^{74}$ Courrier des Pays-Bas, no. 302 (29/10/1828), Marteel (2009, p. 365).

75،"la profonde ignorance des écrivains ministériels en ce qui a rapport à nos lois constitutionnelles et aux principes historiques dont elles émanent".
} 
The debate on press freedom was reopened during the parliamentary session of 28 November 1828 when the Belgian MP De Brouckère argued for the abolishment of the much-hated press laws. In the ensuing debate, other Belgian members expanded the discussion into an inquiry on the nature of constitutional government itself. De Gerlache stated that he could not conceive of "a tempered monarchy without the separation of powers, or an inviolable King without a responsible minister". ${ }^{76}$

He refuted the government's argument that the public law of the United Kingdom exclusively allowed those principles that were explicitly inscribed in the Fundamental Law:

They say that the separation of powers exists in England because it is formally inscribed in the Constitution, whereas this is not the case in our country. The opposite is true, however. There, the separation is considered a necessary condition for constitutional government. It has been introduced by the power of circumstance, since nowhere will you find it in writing. ${ }^{77}$

In his view, constitutional government presupposed a set of principles without which it could not exist, regardless of the exact wording of the Constitution.

In the session of 2 December 1828, Minister Van Maanen denied the existence of ministerial responsibility, by relying on a literal reading of the Fundamental Law:

The Fundamental Law of the Kingdom of the Netherlands is the only compass which should guide us in these matters. Many orators have powerfully defended the principle of ministerial responsibility, but none of them has been able to demonstrate that this responsibility is based on our Fundamental Law. ${ }^{78}$

By confirming the primacy of the Fundamental Law, Van Maanen accused the opposition of violating the Constitution by positing principles that were not explicitly mentioned in it. Indeed, he condemned the opposition's invocation of so-called absolute principles of constitutional government. Constitutional government was a relative concept, he contended, and exclusively related to the prescriptions of each Constitution individually:

(...) the concept of constitutional government is not undetermined and vague, but relative and dependent on the fundamental laws, constitutions or charters of each nation in

\footnotetext{
76،'J'avoue franchement qu'il m'est impossible de concevoir la monarchie tempérée sans la distinction des pouvoirs, de concevoir un Roi inviolable sans un ministre responsable". Handelingen Tweede Kamer 1828-1829, p. 63.

77،"En Anglerre, dit-on, la séparation des pouvoirs existe, parce qu'elle est formellement consacrée par la constitution; et il n'en est pas ainsi chez nous. C'est tout le contraire qui est vrai: cette séparation y est regardée comme une condition nécessaire du gouvernement constitutionnel. Elle s'y est introduite par la force des choses, car vous ne la trouvez écrite nulle part". Handelingen Tweede Kamer 1828-1829, p. 64.

78، $\mathrm{La}$ loi fondamentale du royaume des Pays-Bas seule doit nous servir de boussole dans cette matière; aussi est-il vrai que de tous les orateurs qui se sont si fortement prononcés pour le principe de la responsabilité ministérielle, aucun n'a démontré ni n'a pu démontrer que cette responsabilité est basée sur notre loi fondamentale". Handelingen Tweede Kamer 1828-1829, p. 114. Van Velzen (2005, p. 289).
} 
particular. These fundamental laws constitute our only measure to determine what is constitutional and what is unconstitutional for this or that people. ${ }^{79}$

Jean-François Tielemans published an open letter to Van Maanen in reaction to the latter's speech. ${ }^{80} \mathrm{He}$ started by citing Van Maanen's words on the position of the Fundamental Law as the sole guiding document for establishing the principles of state. He further developed this thought by underlining the inviolability of the Constitution, "the supreme law of all". Since it constituted a binding legal rule for all subjects, any violation of the Fundamental Law automatically implied criminal liability, whether or not the infraction was specified in the Criminal Code:

She must be inviolable, and so she is. He who violates her, be he a King, a Minister, a Magistrate or a private individual, is guilty towards society. The culpability exists, whether or not the act which constitutes the violation is foreseen by the penal code. It exists by the mere fact of the violation of the Fundamental Law, and the culprit henceforward falls under the jurisdiction of the tribunals and of the decent citizens. ${ }^{81}$

He also referred to stipulations in the Criminal Code that made every servant of the state punishable for violations of the Constitution, and to a regulation for the Council of Ministers which prescribed constitutional review for all laws, regulations and administrative measures. ${ }^{82}$

An additional guarantee for the observance of the Fundamental Law had been provided in the form of the oath on the Constitution sworn by every civil servant, from the King down to the humblest clerk. The oath explicitly made the mandate of the servants of the State, including the ministers, juridical. It was intended to make the Fundamental Law even more inviolable:

To be sure, this oath is useless, because in principle it is enough for a law to exist in order for it to entail the obedience of all. But the Fundamental Law of the Netherlands has been placed under the safeguard of the oath so as to make its execution even surer and the rights it consecrated even more inviolable. We must therefore admit that our country possesses a

\footnotetext{
79،“(...) l'idée d'un gouvernement constitutionnel n'est pas indéterminée et vague, mais relative et basée sur les lois fondamentales, constitutions ou chartes de chaque nation en particulier, parce que ces lois fondamentales seules nous donnent la mesure pour déterminer ce qui est constitutionnel ou inconstitutionnel pour tel ou tel peuple". Handelingen Tweede Kamer 1828-1829, p. 113.

${ }^{80}$ On Tielemans: Freson (1932) and Van den Steene (1963, pp. 18-19).

${ }^{81}$ "Elle doit être, elle est inviolable; et celui qui la viole, Roi, Ministre, Magistrat ou particulier, est coupable envers la Société. Pour que la culpabilité existe, il n'est pas nécessaire que l'acte, qui constitue la violation, soit prévu par un code pénal; elle existe par cela même que la loi fondamentale a été violée, et le coupable tombe dès lors sous la jurisdiction des tribunaux ou des honnêtes gens". Tielemans (1829, p. 5).

${ }^{82}$ Tielemans (1829, p. 17).
} 
supreme law, which is sacred, common and superior to both those who govern and those who are governed. He who violates it is responsible towards society, the base of which he undermines, and towards the individuals whose interests and rights he injures. ${ }^{83}$

It followed that the mere fact that the Constitution existed meant that ministers were accountable for any violation of it. The oath simply made this responsibility explicit and legally binding. Tielemans implicitly suggested that, by arguing to the contrary, Van Maanen had in fact denied the Fundamental Law's authority. He insisted that both ministerial responsibility and royal inviolability were inherent in constitutional government. ${ }^{84}$ The alternative was non-responsible government, or in other words, despotism.

The radical politician Adelson Castiau made a similar argument in two pamphlets on ministerial responsibility. ${ }^{85}$ Putting the development of constitutional monarchy in a historical perspective, he emphasized the conceptual unity of royal inviolability and ministerial responsibility as a guarantee for responsible government and a bulwark against despotism. The monarch had received his hereditary mandate and his extensive powers from the Nation, and in return the Nation desired responsible government. ${ }^{86}$ Castiau, too, contented that these principles, although not being prescribed by the letter of the Fundamental Law, were clearly present in its spirit. Ministerial responsibility to Parliament was automatically implied by the idea of representative government, he argued:

Let us never forget that representative government means the government of the opinion, and that as long as it will boldly and resolutely follow the constitutional ways opened up to its expression, the reign of unpopular ministers will be short. ${ }^{87}$

Castiau called the theory of "ministerial irresponsibility" defended by the ministry "a doctrine which is destructive of representative government and undermines all monarchical stability" ${ }^{88} \mathrm{He}$ accused those who argued for it of being "blinded by a Judaic respect for the text of our fundamental law, the spirit of which they fail

\footnotetext{
${ }^{83}$ “'Ce serment, à la vérité, était inutile, puisqu'en principe il suffit qu'une loi existe pour qu'elle entraine forcément l'obéissance de tous; mais en plaçant la loi fondamentale des Pays-Bas sous la sauve-garde du serment, on a pensé que l'exécution n'en serait que plus sûre, et les droits qu'elle consacre plus inviolables. Nous devons donc le reconnaître: notre pays possède une loi suprême, sacrée, commune et supérieure aux gouvernans comme aux gouvernés. Quiconque la viole est responsable envers la société dont il ébranle la base, et envers les individus dont il blesse les intérêts et les droits". Tielemans (1829, p. 5).

${ }^{84}$ Tielemans (1829, p. 10).

${ }^{85}$ On Castiau: Philippart (1984).

${ }^{86}$ Castiau (1829a, p. 2).

${ }^{87}$ “N'oublions jamais que le gouvernement représentatif est le gouvernement par l'opinion, et qu'aussi longtemps qu'elle suivra, avec fermeté et hardiesse, les voies constitutionnelles ouvertes à son expression, le règne d'un ministre impopulaire sera de courte durée". Castiau (1829a, p. 28).

88، "une doctrine destructive du gouvernement représentatif et subversive de toute stabilité monarchique". Castiau (1829a, p. 10).
} 
to understand". ${ }^{89}$ Castiau emphasized the legally binding character of the Fundamental Law on which these principles were based. Those officials who denied their existence made themselves guilty of perjury, legitimizing revolt and anarchy. Indeed, he reminded the ministers that the Nation automatically had the right to resist the government in case the latter violated the legal order:

(...) they know, as we do, that on the day when power abandons legality, legality moves over to the side of the resistance. ${ }^{90}$

With this last quote, Castiau anticipated the arguments that would later serve as the legitimation for the Belgian Revolution.

For Tielemans, Castiau and their sympathisers, the Fundamental Law implied all the principles of modern constitutional monarchy. This meant, according to them, that it should be read in the spirit of Benjamin Constant. Not doing so, they contended, automatically resulted in paradoxes and absurdities. The principles in question therefore did not need to be spelled out in the Constitution in order to be logically presupposed. Many in the opposition called for an explicit mentioning of ministerial responsibility in the laws, in order to prevent the ministers from further exploiting the ambiguities of the existing formulation. Castiau rejected this proposal though, stating that the Constitution already contained sufficient guarantees. ${ }^{91}$ In his view, it was an illusion to think that a more explicit formulation would stop ministers from abusing their powers. An admirer of Constant, he counted on the active surveillance of an independent national representation and a well-informed public opinion as the only effective means to control the government.

In their defense of the government, the ministerial pamphleteers targeted this supposed spirit of the Constitution. By appealing to a minimalistic interpretation, they succeeded in keeping its status as legally binding basic rule intact, while at the same time restricting its impact radius to a minimum. ${ }^{92}$ The ministerial point of view was expounded in a range of pamphlets, all of which explicitly referred to the Fundamental Law. In his speech of 2 December 1828, Van Maanen set the tone by disclaiming any constitutional principle that did not literally figure in the Constitution. Ministerial authors developed this argument, accusing the opposition of intentionally misinterpreting the Constitution for their own particular interest.

\footnotetext{
89،"aveuglés pas un respect judaïque pour le texte de notre loi fondamentale, dont ils méconnaîtraient l'esprit". Castiau (1829a, p. 10).

90 “(...) ils savent, comme nous, que le jour où le pouvoir abandonne la légalité, cette dernière passe du côté de la résistance". Castiau (1829a, p. 12).

${ }^{91}$ Castiau (1829a, pp. 24-39). He made an exception for the ministerial countersign, judging that the silence of the Constitution on this issue was deplorable. However, since neither the English nor the French Constitutions contained provisions on this point, he denied that it could be used as an argument against the existence of ministerial responsibility. Castiau (1829b, pp. 17-18).

${ }^{92}$ Marteel (2009, p. 365) and Van Zanten (2005, p. 290).
} 
Such was the reasoning of C. Asser, in his anonymously published pamphlet $D e$ la responsabilité ministérielle d'après le droit public du Royaume des Pays-Bas. ${ }^{93}$ He started with a worried remark on the newspapers' perversion of the most precious constitutional prerogatives:

Every Belgian who loves his country and who attentively examines the spirit and the tendency of some of our newspapers, must be troubled by the deplorable abuse made of our most precious constitutional prerogatives. ${ }^{94}$

Such exaggerated claims as those made by the oppositional newspapers could only be the work of foreign troublemakers

who, being indifferent to the prosperity of our fatherland, and having no knowledge at all of our customs and of our laws, apply principles which our Fundamental Law refutes to our public law. ${ }^{95}$

Since the Constitution did not contain any article in support of their claims, these people invoked the constitutions of England and France instead. By doing so however, they seemed to forget that the Fundamental Law constituted the sole legal ground of public law in the United Kingdom:

(...) the rights of the Belgian subjects, as well as the rights of the government, are determined only by the pact concluded between the head of state and the Nation. These rights are mutually sealed under the oath. ${ }^{96}$ We must rely only on the principles of OUR public law, and exclusively invoke the dispositions of our Fundamental Law. ${ }^{97}$

The principles of the Fundamental Law could be deduced exclusively from the articles and dispositions it contained. It could not be induced from any theory of constitutional monarchy outside of the constitutional text. For Asser, claiming that constitutional government by definition implied ministerial responsibility was the same as pretending that:

\footnotetext{
${ }^{93}$ Van Kuyck (1914). Asser was a public servant at the Council of State and a personal friend of Van Maanen. The brochure was published on the latter's initiative to support Van Maanen's denial of ministerial responsibility in the Estates General on 2 December 1828. Van Velzen (2005, p. 290).

94،Tout Belge, ami de sa patrie, qui examine d'un œil attentif l'esprit et la tendance de quelques-uns de nos journaux, s'afflige sans doute de l'abus déplorable que l'on fait d'une de nos prérogatives constitutionnelles les plus précieuses". Asser (1828, p. 1).

95“"qui sont indifférent à la prospérité de notre pays et qui, sans aucune connaissance de nos mœurs et de nos lois, viennent appliquer à notre droit public des principes repoussés par notre Loi Fondamentale". Asser (1828, p. 1).

96، (...) les droits des sujets belges, aussi bien que ceux du gouvernement, sont uniquement déterminés par le pacte conclu entre le chef de l'Etat et la nation, et réciproquement scellé sous la foi du serment". Asser (1828, p. 2).

97، (...) nous ne devons nous appuyer que sur les principes de NOTRE droit public, et n'invoquer que les dispositions de notre Loi Fondamentale”. Asser (1828, p. 3).
} 
the words Fundamental Law, Charte, Constitution, are not undetermined expressions when taken individually, and that it is possible to understand their meaning, their nature and their extent by other means than by the principles and dispositions which they contain. ${ }^{98}$

The King himself had insisted on limiting his power by introducing a liberal Constitution, but he was completely free to act within the circle of his constitutional competences.

The government reacted to the Courrier des Pays-Bas' criticism in a anonymously published pamphlet entitled Quelques observations fondées sur les termes exprès de la Loi Fondamentale. ${ }^{99}$ The title perfectly illustrates the way in which the ministerial writers turned the opposition's constitutional logic to their advantage. The author, Tielman Olivier Schilperoort, repeated Van Maanen's state theory by stating that sovereignty emanated from the King only. The latter had granted a Constitution of his free will. ${ }^{100}$ The opposition's mistake was to confuse constitutional government with representative government. Sovereignty consisted of both the legislative and executive powers and was entirely in the hand of the monarch:

The great goal of a Fundamental Law in a constitutional state is to prevent those shocks and revolutions, by expressly determining the exercise of sovereignty (...), not by the separation of powers but by their union. ${ }^{101}$

It followed that the Fundamental Law did not allow for ministerial responsibility to Parliament. Having sworn to maintain the Constitutional in all its aspects, it was the King's duty to refute the unfounded and unconstitutional demands of the opposition:

In his inaugural oath, the King swears, among other things, that he will not tolerate any deviation from the Fundamental Law, on whatever occasion and on whatever pretext. Thus, the King has personally engaged himself to maintain the fundamental pact against every aggression, even those instigated by ignorant or exaggerating writers. ${ }^{102}$

Baron Goubau d'Hovorst defended the ministerial point of view in his speech for the First Chamber on 16 May 1829. ${ }^{103}$ The goal of his intervention was to

\footnotetext{
98“"les mots de Loi Fondamentale, Charte, Constitution, n'étaient pas des expressions indéterminées lorsqu'on les prend isolément, et comme s'il était possible de connaître leur sens, leur nature et leur étendue, autrement que par les principes et les dispositions dont elles sont composées". Asser (1828, p. 14).

${ }^{99}$ Olivier Schilperoort (1828), Some observations founded on the express terms of the Fundamental Law. Zuidema (1921) and Van Velzen (2005, p. 289).

${ }^{100}$ Olivier Schilperoort (1828, p. 12).

101، 'Le grand but d'une Loi fondamentale d'un état constitutionnel est de prévenir ces chocs et ces révolutions, en déterminant d'une manière expresse l'exercice de la souveraineté, non (...) par la séparation des pouvoirs, mais par leur union”. Olivier Schilperoort (1828, p. 10).

102،'Le Roi (...), par le serment inaugural, (...) jure entr'autres qu'il ne souffrira pas qu'on s'écarte de la Loi Fondamentale, en aucune occasion, ni sous aucun prétexte. C'est ainsi que le Roi a pris l'engagement personnel de maintenir le pacte fondamental contre toutes agressions, voire même celles de l'ignorance ou de l'exagération des écrivains". Olivier Schilperoort (1828, p. 5).

${ }^{103}$ Varenbergh (1884-1885) and Van Velzen (2005, p. 315).
} 
investigate whether the oppositional demands, expressed in the recent petitioning campaign, were admissible. ${ }^{104}$ Not surprisingly, he systematically rejected the demands, grounding his refutation on articles of the Fundamental Law. On the subject of the role of the government in the organization of public education, he disclaimed the opposition's demand by pointing out that it harmed the constitutional order:

This reverses the order instated by Art. 226 of the Fundamental Law, and it evidently harms both the ancient and the modern rights of the Sovereign of the Netherlands. ${ }^{105}$

On the same grounds he argued against ministerial responsibility:

Those who demand ministerial responsibility are blinded: given the organization of our Kingdom and the way in which things are being done here, introducing it would require changing the Fundamental Law. ${ }^{106}$

Such a system was not admissible without a change of Constitution. Goubau-d'Hovorst, also refuted the idea that a constitutional government was impossible without ministerial responsibility:

Our government will be a constitutional government of a special kind (...). As long as it exists, one must march with it just as it is, and religiously adhere to the prescriptions of the Fundamental Law on which it is founded. ${ }^{107}$

He concluded by warning against the dangers of the petition movement, which aroused passions and effervescence in the people. All this militant invocation of constitutional rights reminded him of the Brabant Revolution, which he had witnessed himself, and its Northern counterpart, the Patriot uprising against stadtholder William V:

What we are witnessing today is taking the same turn as in those times when one spoke of nothing else but the Joyeuse Entrée, just like today one speaks of nothing else but the Fundamental Law. ${ }^{108}$

\footnotetext{
${ }^{104}$ On the petition campaigns: Harsin (1930, p. 53), Tamse and Witte (1992, p. 36), Wils (2009, p. 50) and Witte (2006, p. 79).

${ }^{105}$ “C'est renverser l'ordre établi par l'art. 226 de la Loi Fondamentale, et porter évidemment atteinte aux droits tant anciens que modernes du Souverain des Pays-Bas". Goubau-d'Hovorst (1829, p. 18).

106، Ceux qui demandent cette responsabilité parlent en aveugles: d'après la manière que notre Royaume est organisé et que les affaires s'y traitent, pour l'introduire, il faudrait changer la Loi Fondamentale". Goubau-d'Hovorst (1829, p. 23).

107،Notre gouvernement sera un gouvernement constitutionnel d'un genre particulier (...). Tant qu'il existe, il faut marcher avec lui tel qu'il est, et se tenir religieusement à ce que prescrit la Loi Fondamentale sur laquelle il est basé”. Goubau-d'Hovorst (1829, p. 25).

${ }^{108}$ “'Ce que nous voyons aujourd'hui prend la même marche que dans ces temps-là, on n'avait à la bouche que la Joyeuse Entrée, comme aujourd'hui on n'a à la bouche que la Loi Fondamentale". Goubau-d'Hovorst (1829, p. 50). The Joyous Entry was the inaugural charter of the Dukes of Brabant, on which the Brabant revolutionaries based their claims.
} 
To allow the petition movement to continue would be to expose the state to the danger of another disorderly uprising based on a faulty reading of the Constitution.

Time and again the ministerial apologists denied the opposition's claim that constitutional government implied a fixed set of unalterable principles, and that the Fundamental Law consecrated these principles by necessity. Only the letter of the Constitution defined the state system of the United Kingdom. Appeals to any other source, text or theory than the Constitution itself were ipse facto irrelevant. Indeed, every Constitution needed to be understood and analyzed individually, and not on the basis of a set of presupposed common principles:

Let us conclude from what precedes that, since every constitution must be judged after its own tenor and its own spirit, we can never invoke the institutions of other nations when commenting on our Fundamental Law and determining the nature and the implications of its dispositions. These nations share with us only the fact of being ruled by constitutional laws. Apart from that, they are far from finding in these laws the same guarantees as we do in ours. ${ }^{109}$

In his Royal Message of 11 December 1829, the King himself confirmed the views on sovereignty propagated by his government, and formally denied the existence of ministerial responsibility to Parliament. ${ }^{110}$

\subsection{Towards a New Legal Order}

As we have seen, respect for the existing legal order based on the Fundamental Law was central to the argumentation of both the government and the opposition. Over time, both Liberals and Catholics within the Belgian opposition turned to modern constitutionalism as the surest way to realize their respective programs. Liberal campaigning for modern constitutionalism in the spirit of Benjamin Constant already began in 1814, with Van Meenen's publication on the topic. ${ }^{111}$ The next generation of Liberals built upon his ideas and further developed them in newspapers such as Le Politique, Le Courrier des Pays-Bas and L'Emancipation. ${ }^{112}$ Catholic thinking underwent a more fundamental transformation over time, as

\footnotetext{
109“'Tirons de ce qui précède la conséquence que, toute constitution devant être jugée d'après sa teneur et son esprit, nous ne pouvons jamais, lorsqu'il s'agit de commenter notre Loi Fondamentale et de déterminer la nature et l'étendue de ses dispositions, invoquer les institutions d'autres nations qui n'ont de commun avec nous que d'être également régies par des lois constitutionnelles, mais qui, au reste, sont loin de trouver dans ces lois les garanties qui nous ont été assurées par les nôtres". Asser (1828, p. 20).

${ }^{110}$ Bijlagen Handelingen Tweede Kamer 1829-1830, pp. 741-743. Marteel (2012, p. 54), Van Velzen (2005, p. 329) and Worst (1992, p. 72).

${ }^{111}$ Le Roy (1897), Marteel (2009, p. 49), Van den Steene (1963, pp. 17-19).

${ }^{112}$ Harsin (1930), Vermeersch (1992), Witte (1979) and Wouters (1958).
} 
Stefaan Marteel showed in his meticulous reconstruction of the development of Catholic thought under the United Kingdom. ${ }^{113}$ The Old Regime ideal of a Catholic state Church dwindled as Belgian Catholics were confronted with a Protestant King intent on closely supervising the spheres of religion and education. ${ }^{114}$ The idea that the autonomy of the Church would be better guaranteed by a separation of Church and State and the proclamation of absolute religious freedom, gained popularity.

Despite their radically different outlooks on society, the oppositional groups came to agree on the central importance of the constitutional text. When both groups joined forces in 1827, their key demand was the exact implementation of the Fundamental Law in all its points. ${ }^{115}$ This implied not only recognition of the liberties and the division of powers enshrined by it, but also of its binding legal force. The issue of ministerial responsibility, which raised the most controversy between the two parties, went to the core of this idea. It implied making the Constitution's role as the normative rule for the actions of the executive power legally enforceable. As mentioned before, Art. 177 of the Fundamental Law foresaw the creation of a High Court for the judgement of ministers accused of violating the Constitution. The article remained a fiction however, since the government postponed the creation of the Court indefinitely. ${ }^{116}$ The opposition in turn accused it of causing legal insecurity. Likewise, the opposition opposed the absence of legal means to dispute the introduction of unconstitutional laws, such as the ones against the freedom of the press.

The course of events suggests that the government only explicitly adopted a constitutional discourse in reaction to the opposition's incessant claims based on the Fundamental Law. It succeeded in turning these claims to its advantage by developing its own, minimalist interpretation of the Constitution and using it to denounce the oppositional demands as illegal. The logic of legal order turned to the opposition's disadvantage at the moment when events took a revolutionary turn. Riots broke out in Brussels against the Dutch government during the night of the 25 August 1830. ${ }^{117}$ In the succeeding weeks new power structures emerged on the local level which gradually replaced the official ones. The government tried to appease the rioters by giving in to many of the opposition's demands, including the dismissal of the unpopular minister Van Maanen. ${ }^{118}$

\footnotetext{
${ }^{113}$ Marteel (2009).

${ }^{114}$ Marteel (2009, pp. 265-320).

${ }^{115}$ Marteel (2009, p. 347).

${ }^{116}$ Van Velzen (2005, p. 175). Marteel, on the other hand, argues that the debate on the High Court had no bearing on the Southern opposition's demand for ministerial responsibility. Marteel (2009, p. 242).

${ }^{117}$ Witte (2006, p. 51).

${ }^{118}$ Van Velzen (2015, p. 58), Witte (2006, p. 57), Witte (2016, p. 16). Although William I went as far as to dismiss Van Maanen, conceding on the point of ministerial responsibility was impossible for him. It would have changed the very nature of his rule, which he saw as the ultimate guarantee for the country's stability. The opposition continued to press this point, as a fundamental transformation in the exercise of power was exactly what it aimed for.
} 
In the meantime, the opposition was confronted with the paradox of on the one hand invoking the Fundamental Law and on the other hand, waging armed-and thus illegal-protest. The oppositional press continued to refer to the Fundamental Law to legitimatize their demands. The newspaper Courrier des Pays-Bas encouraged the Belgian delegates to the Estates General to persist in their "legal resistance" against "the violations of the Fundamental Law" and against the "anti-constitutional projects of the ministers". It confirmed that what the opposition desired was respect for the will of the Fundamental Law, and added: "We repeat that we are neither waging a revolution nor an insurrection". ${ }^{119}$ The Courrier de la Sambre called on the Fundamental Law to protest against the convocation of the Estates General in The Hague instead of Brussels even though it was the latter city's turn to serve as the capital:

The convocation of the Estates General in The Hague is a formal violation of the Fundamental Law. In the present circumstances, this violation may produce fatal results unless it is legally resisted. ${ }^{120}$

The French newspaper Le Constitutionnel commented: "The insurrection is definitely national and constitutional". ${ }^{121}$ Radical newspapers on the other hand accused the Belgian members of the Estates General attending the meeting of the Estates in The Hague of being in league with a government that repressed the rights of the Belgian Nation.

The legitimacy of the opposition was at stake. Thus far, the Fundamental Law had provided the ultimate legal basis for its claims. By opting for open rebellion, the opposition risked invalidating its whole enterprise, as well as alienating those citizens who wished to remain within the legal order. King William put the finger on the sore spot when, in his proclamation of 5 September 1830, he denounced the insurgents' revolt against the legal order. William called the opposition's "return into the legal order" a precondition for opening negotiations over the Belgian demands. ${ }^{122}$ The proclamation caused a change in tone in the oppositional newspapers, who took offense at the King's minimisation of the conflict and his use of the term insurgents. As the government seemed to refuse to take the Belgian grievances seriously, the legality of the existing order itself was increasingly called into question. The Courrier des Pays-Bas commented:

We are no longer under the legal order organized by the Minister Van Maanen, because that legal order was tyrannical for us. Since it is nothing but organized oppression

\footnotetext{
119“Nous le répétons, nous ne sommes ni en révolution, ni en insurrection”. Courrier des Pays-Bas no. 244, 01/09/1830.

120، 'La convocation des états-généraux à La Haye est une violation formelle de la loi fondamentale, violation qui pourrait dans l'état des choses avoir les plus funestes résultats, sil l'on ne s'y opposait légalement". Courrier de la Sambre no. 134, 6/09/1830.

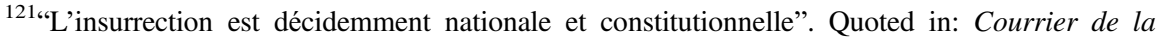
Sambre no. 140, 13/09/1830.

${ }^{122}$ Courrier des Pays-Bas no. 252, 09/09/1830.
} 
covered with a varnish of legality, this supposed legal order must be modified and changed. $^{123}$

We must return into the legal order. The legal order! It is easier said than done. This order, which Mr. Van Maanen had organized so well, and which is the fruit of fifteen years of oppression, is exactly the object of our complaints. ${ }^{124}$

The newspaper contested the legality of the existing order on account of its tyrannical character and of the harm it caused to the Belgian Nation. ${ }^{125}$ Le Vrai Patriote maintained that a people was free to choose a new leader when the social contract was violated. ${ }^{126}$ As the opposition left the legal order behind, the rights of the nation were cited as the only legitimate source of authority. The Courrier de la Sambre wrote:

Do not tell us that we need the consent of the Estates General. We are now outside of the legal order. Every measure is legal at present, as soon as it is founded on the approval of the nation. $^{127}$

The bloody September Days in Brussels brought about the final turnabout. The killing of Belgian citizens by the Dutch troops was presented as a final attack on the Belgian Nation by which the Dutch government forfeited its remaining claims to legitimate authority. The Provisional Government of Belgium was created in the wake of the events. The Courrier des Pays-Bas proclaimed that the only legitimate source of authority in the contemporary world was the people's right to self-determination. ${ }^{128}$ From that moment on, respect for the old legal order need not concern the Belgians any more, the newspapers agreed:

\footnotetext{
123،Nous ne sommes plus dans l'ordre légal tel que le ministère Van Maanen l'avait organisé, parce que cet ordre légal était tyrannique pour nous, et ce prétendu ordre légal n'étant autre chose que l'oppression organisée et couverte d'un vernis de légalité, c'est lui qu'il faut modifier et corriger". Courrier des Pays-Bas no. 256, 13/09/1830.

124،"Il faut rentrer dans l'ordre. L'ordre! C'est chose aisée à dire, mais cet ordre que M. Van Maanen a si bien arrangé et qui est le fruit de quinze ans d'oppression, c'est précisément l'objet de nos plaintes". Courrier des Pays-Bas no. 260, 17/09/1830.

${ }^{125}$ “Cet ordre, c'est l'oppression de le Belgique systématiquement organisée avec un faux semblant de légalité". Courrier des Pays-Bas no. 260, 17/09/1830.

${ }^{126}$ Le Vrai Patriote no. 29, 10/11/1830.

127،Et qu'on ne dise pas qu'il faut le consentement des états-généraux; nous sommes aujourd'hui en dehors de l'ordre légal; toute mesure est légale en ce moment dès qu'elle a pour base l'assentiment de la nation". Courrier de la Sambre no. 137, 09/09/1830.

128، Aujourd'hui ce n'est pas le fait antérieur, ni les convenances de tel souverain qui peuvent autoriser sans leur consentement respectif la réunion de deux peuples en une seule famille politique. Le principe qui a triomphé en septembre est l'association consentie. (...) Le principe de l'association consentie, est aujourd'hui tellement inhérent au principe du gouvernement populaire, que le règne de la liberté ne pourra pas autrement s'établir en Europe, qu'en laissant à chaque peuple la faculté de s'unir à l'association politique qui est le plus conforme à ses vœux". "Nowadays neither prior facts nor the liking of such or such sovereign can authorise, without their respective consents, the reunion of two peoples into one political family. The principle which has triumphed in September is that of consented association. (...) The principle of consented association is today so inherent to popular government that the reign of liberty cannot establish itself in Europe but by leaving each people the faculty to unite with the political association most conforming to its wishes".
} 
(...) this question has been answered during the days of 23, 24, 25 and 26 September; this solution had to be solemnly announced; it is the only title of the Provisional Government; it is the source of its legitimacy. ${ }^{129}$

The opposition overcame the revolutionary paradox by basing its legitimacy on a natural law norm that transcended the legal order: the rights of the Nation. Since the existing legal order, enshrined by the Fundamental Law, seemed only harmful to its interests, the Nation legitimately demanded the establishment of a new one. Henceforward, the despotism of the Dutch government was invoked as the legal ground for Belgian independence. ${ }^{130}$ On 4 October 1830, the Provisional Government declared Belgian independence in the name of the revolutionary Belgian people. ${ }^{131}$ Two days later, it decreed elections for a National Congress and the creation of a Constitutional Commission to draw up a draft Constitution. ${ }^{132}$ It was stressed that the present situation was a provisional one, aimed at establishing a legal order consecrated by a new Constitution drawn up by the representatives of the Nation.

Although the Fundamental Law was discarded in the process, the discourse of constitutional legitimation remained intact. The constituent debates received priority in the National Congress even though the young state was faced with pressing political, economic and military needs. Despite the fact that many were critical of both the draft Constitution's conservative slant and the "excessive" time spent on debating it, protests against prioritizing the constitutional issue were few and far between. ${ }^{133}$ Newspapers articulated high expectations for the new Constitution, while many private individuals published their own constitutional drafts or addressed them to the Congress. ${ }^{134}$ The Belgian Constitution was clearly expected to become what the Fundamental Law had failed to be: an immutable basic rule (a "law of laws" according to the Journal d'Anvers) which, by guaranteeing the liberties of the citizens and clearly defining the division of powers, assured the future wellbeing of the state. ${ }^{135}$

\footnotetext{
${ }^{129}$ “ (...) cette question a été résolue dans les journées de 23, 24, 25 et 26 septembre; c'est cette solution qu'il fallait solennellement faire connaître; c'est le seul titre du gouvernement provisoire; il y puise sa légitimité". Courrier des Pays-Bas no. 278, 05/10/1830.

${ }^{130}$ See the opening speech of Louis de Potter for the National Congress on 10 November 1830 , Huyttens (1844-1845), vol. 1, p. 100. E.g. the speech by Etienne de Gerlache as president of the Congress at the occasion of the inauguration of the Regent on 25 February 1831: "Il est arrivé qu'un prince, plein de préjugés et d'entêtement, s'est imaginé qu'une nation lui appartenait parce qu'on la lui avait cédée par traités; il a cru pouvoir la tromper toujours, avec un système de constitution qu'il tournait et violait à son gré, lui imposer sa langue, sa religion, ses créatures: cette nation fait une révolution, et le prince est renversé et puni”. Huyttens (1844-1845), vol. 2, p. 595.

${ }^{131}$ Bulletin des arrêtés et actes du Gouvernement Provisoire de la Belgique (1830), no. 4, p. 3 , decree of 4 October 1830.

${ }^{132}$ Bulletin des arrêtés et actes du Gouvernement Provisoire de la Belgique (1830), no. 5, p. 13, decree of 6 October 1830.

${ }^{133}$ Magits (1977), vol. 1, p. 391.

${ }^{134}$ Magits (1977), vol. 1, pp. 333-379.

${ }^{135}$ Journal d'Anvers, 18-19 October 1830.
} 
The discourse of the Belgian newspapers on the Fundamental Law underwent a drastic transformation in the meantime. Independence, and the prospect of a new Constitution, left the Fundamental Law bereft of the support it had formerly enjoyed in Belgium. Not only had it been introduced against the will of the Nation, as the newspapers were keen to remember, it had also failed to protect the Nation against royal despotism. It came to be considered the tool of a Machiavellian regime. On the eve of the proclamation of the Belgian Constitution, the radical newspaper Courrier de la Sambre wrote:

This work of iniquity called the Fundamental Law, was destined to be the straightjacket of two peoples (...). There was no other option than to bow to this Machiavellism for fifteen long years, and even, in the last years, to invoke it as the anchor of salvation. ${ }^{136}$

The newspaper considered it ironic that the Belgians had been reduced to calling on the Fundamental Law as their last resort against royal despotism, when it had served as the support of that very regime in the first place.

Only one year earlier, on 22 January 1830, the same newspaper had written about the Fundamental Law in strikingly different terms:

All demand the pure and simple execution of the Fundamental Law, and should the government dare to boldly lay violent hands on this sacred arch, and venture to commit a coup by suspending and annulling the Constitution.... ${ }^{137}$

In his history of the United Kingdom of the Netherlands, Etienne de Gerlache later commented that the extreme disdain with which the Belgian founding fathers treated the Fundamental Law was unwarranted, since the problem was not the charter itself but its interpretation. ${ }^{138}$ De Gerlache's analysis is confirmed by the fact that no less than $40 \%$ of the articles of the Belgian Constitution were copied from the Dutch Fundamental Law. ${ }^{139}$ Indeed, what had been at stake for the Belgian opposition was not the exact wording of the Fundamental Law but the recognition of the principles of modern constitutionalism which it considered to lay at its base. Because of the government's refusal to recognize these principles, the

\footnotetext{
${ }^{136}$ “Cette œuvre d'iniquité, qui, sous le nom de loi fondamentale, devait être la camisole de force de deux peuples. (...) Force fut donc de ce soumettre pendant 15 longues années à ce machiavelisme; force même fut, dans les dernières, de l'invoquer comme ancre de salut". Courrier de la Sambre, 6/02/1831.

137 “. (...) tous réclament l'exécution pure et simple de la Loi fondamentale: et si le pouvoir avisait de porter une main téméraire sur cette arche sainte et se permettait de frapper un coup d'état en suspendant la constitution et en la déclarant anéantie (...)". Courrier de la Sambre, 22/01/1830. 138، La loi fondamentale de 1815, amalgame des vieilles idées belges et hollandaises, et des nouvelles idées françaises, ne méritait peut-être pas le dédain extrême avec lequel la traitèrent nos constituans de 1831. Ce ne fut point tant cette charte qui engendra les griefs, que le mauvais esprit qui l'interprétait'. De Gerlache (1859), vol. 2, p. XXIII. Louis de Potter started his opening speech for the National Congress by calling to mind the despotic way in which the Fundamental Law had been "forced by Holland" upon the Belgians. However, he conceded that its failure to secure liberty in Belgium was not so much due to its inherent character as to the fact of its incomplete execution. Huyttens (1844-1845), vol. 1, p. 100.
}

${ }^{139}$ Gilissen (1967, p. 60). 
Fundamental Law had not succeeded in creating the immutable legal and political order of which it was supposed to be the guardian.

\subsection{Constituent Power}

The new Constitution was debated and adopted in a relatively short span of time. After being accepted on 7 February 1831, it was solemnly promulgated on 11 February. The completion of the Constitution raised questions about the mandate of the Congress, and about the question of whether or not it should retain its constituent power. There was a general desire that the Constitution should enter into force and become the single legal norm for the new country. However, the political situation was not yet settled: a candidate for the throne still needed to be found, and the international situation remained unclear. Some members argued that now that the constituent work was done, the Congress no longer had a reason to exist. However, most objected to this view and insisted that order should return before elections for a regular Parliament could be called. In the meantime the Congress would continue to legislate. ${ }^{140}$

The provisional state of affairs was hard to reconcile with the desire for an immutable basic rule. It had originally been decided that the Constitution would come into force on the eleventh day after its proclamation, just like ordinary decrees. ${ }^{141}$ At several points in time, questions arose over the constituent mandate of the Congress. For as long as it retained its constituent power, the Constitution was susceptible to change. Van Meenen therefore proposed to immediately promulgate the Constitution, but to make it obligatory only from the moment when the Congress proclaimed its own dissolution. He rejected the idea, favored by some, that only the monarch's acceptance of the Constitution could render it binding. Although he conceded that the Constitution established a contract between the monarch and that Nation, he denied that the former should be allowed to have any influence on its content. His accession to the throne depended on his prior acceptance of the Constitution in all its points:

It has been suggested that the Constitution will only become definite upon its acceptance by the head of state. It is true that a contract is being established between him and the Nation, but the Constitution is not the subject matter of that contract; it is the acceptance of the mandate conferred to him by the Nation. The mandator in this case is the collective being that is the constituted Nation. The [King's] acceptance cannot call into question parts of the contract. Otherwise, every employee, when entering into function, could simply refuse to accept the laws he was called upon to execute unless modifications were made. ${ }^{142}$

\footnotetext{
${ }^{140}$ Huyttens (1844-1845), vol. 2, p. 501, 11/02/1831.

${ }^{141}$ Huyttens (1844-1845), vol. 1, 27/11/1830.

142،'On a dit qu'elle [la Constitution] ne serait arrêtée définitivement que par l'acceptation du chef de l'État. Il est vrai qu'il se forme un contrat entre lui et la nation, mais la constitution ne forme pas la matière de ce contrat, c'est l'acceptation du mandat que lui confère la nation. Le mandant est ici
} 
Destouvelles made a similar comparison in order to stress the monarch's subordination to the Constitution, and to insist that he had no other choice than to accept its terms: "a Constitution is only the specification of that acceptance". ${ }^{143}$ The Congress confirmed this reasoning by deciding for the Constitution's immediate promulgation, but making it obligatory only ten days after the dissolution of the Congress. There could be no doubt that the future monarch derived his powers exclusively from the Constitution as a prior legal norm, and not from any extra-constitutional source of sovereignty (as in the case of William I's 'preliminary sovereignty').

The decision entailed a new debate on the question of whether or not proclaiming the Constitution meant that the Congress would abandon its constituent powers. Van Meenen maintained that the Congress should not be allowed to make any further changes to the Constitution after its proclamation, except for filling the gaps it inevitably contained. He was supported by, among others, Lebeau, who said that this was the best way to prevent external powers (namely the London Conference and/or the future monarch), from pressuring the Congress into adapting the Constitution to its wishes. The republican members Van Snick and De Robaulx objected to this measure, maintaining that a Congress vested with constituent powers would always be able to retract previous decisions, including those pertaining to the text of the constitution. The reason for their protest was clear enough. Since the Constitution specified that Belgium was a "representative, constitutional monarchy", a binding proclamation would stand in the way of the introduction of the republican form of government. Anticipating the Duc de Nemours' refusal of the Belgian Crown, De Robaulx brought forward a bill in favor of the immediate proclamation of the republic. He pointed out that the Congress was not a normal legislative assembly but a sovereign constituent assembly. Since it was omnipotent, its powers could not be bound even by its own decisions:

If I were to make a proposal contrary to a constitutional decree in a legislative assembly, I could imagine that one moves to the previous question; but in a constituent assembly, this is inadmissible, since we are sovereign judges, and have the power to reform ourselves. ${ }^{144}$

The proposal was not taken into consideration.

The Duc de Nemours's refusal, which De Robaulx had predicted, meant that the preconceived timing could not be followed. The search for a candidate for the

un être collectif de la nation constituée. L'acceptation ne peut mettre en question toutes les parties du contrat. S'il en était autrement, chaque employé n'aurait qu'à dire, en entrant en fonctions, qu'il n'accepte que sauf des modifications à faire aux lois qu'il est appelé à exécuter". Huyttens (18441845), vol. 2, p. 492, 08/02/1831.

143، "une constitution n'est que le cahier des charges de cette acceptation”. Huyttens (1844-1845), vol. 2, p. 492, 08/02/1831.

${ }^{144}$ “' $\mathrm{Si}$, dans une assemblée législative, je faisais une proposition contraire à un décret constitutionnel, je concevrais que l'on pût invoquer la question préalable; mais dans une assemblée constituante, elle est inadmissible parce que nous sommes juges souverains, et en possession du pouvoir de nous réformer nous-mêmes". Huyttens (1844-1845), vol. 2, p. 512, 14/02/1831. 
throne needed to be reopened, and the Congress would continue to convene. However, the Congressmen wished more than anything to leave the provisional order behind and put the Constitution into force. The credibility of the new state depended on it, both domestically and towards its neighbors. Van de Weyer stated: "it will signal the coming into force of our institutions. It will signal the organization of a regulated and truly constitutional power". ${ }^{145}$

On the proposal of Lebeau, and in concordance with Art. 85 of the Constitution, it was decided that a Regent should be appointed. ${ }^{146}$ Since the Constitution would enter into force from the moment the Regent took the oath, this would put an end to the provisional state of affairs. The Congress nevertheless retained constituent power until a King was inaugurated, at which moment it would adjourn and elections for a regular Parliament would be called. The Congress would only be dissolved definitively when the new Parliament was installed.

\subsection{The Question of Constitutionality}

The temporary state of affairs created another complication with regard to the precedence of Constitution, namely the issue of constitutionality. Even before the Constitution was promulgated, the question arose whether or not the constituent Congress should act in accordance with it. For a start, a debate emerged on the issue of whether or not the proposed regency needed to be organized along the lines of article 85 of the Constitution. The constituent Congress did not really match the prescriptions of the article, which had been drawn up with a normal legislative assembly in mind. Nothomb argued that the Congress was entirely free to instate a regency according to its own wishes:

The regency we wish to install does not figure in the fundamental law; the existence of the Congress vested with constituent powers makes our situation totally exceptional. In this regard, the Congress is not bound by any Constitution. We can neither abdicate the constituent power, nor delegate part of it. We are bound by our mandate. ${ }^{147}$

Since the Congress was an omnipotent constituent power, it acted outside of any Constitution, even the one it had itself created. Alexandre Gendebien objected that, since the Constitution provided for the possibility of a regency, the Congress was bound to abide by its prescriptions:

145“ “... ce sera le signal de la mise en pratique de nos institutions, ce sera le signal de l'organisation d'un pouvoir réglé et vraiment constitutionnel". Huyttens (1844-1845), vol. 2, p. 580, 23/02/1831.

${ }^{146}$ Huyttens (1844-1845), vol. 2, p. 580, 23/02/1831.

${ }^{147}$ “La régence que nous voulons instituer n'est pas dans la loi fondamentale; l'existence du congrès investi du pouvoir constituant rend notre situation tout à fait exceptionnelle; le congrès est à cet égard en dehors de toute constitution. Nous ne pouvons abdiquer le pouvoir constituant, ni le déléguer en partie. Nous sommes liés par notre mandat”. Huyttens (1844-1845), vol. 2, p. 581, $23 / 02 / 1831$. 
Your Constitution is ready, now it must be put into action. You are short of a King though. Article 85 of the constitution prescribes that, when the throne is vacant, the administration of the realm is provided for by a regency. ${ }^{148}$

Not to do so would be to violate the Constitution even before it came into force:

To allow for the proposals which have been brought before you would be unconstitutional, and I do not think you wish to violate the fundamental pact even before it is put into action. $^{149}$

The Congress finally followed Nothomb's reasoning. It instated a regency of its own design, with a Regent who did not possess all the constitutional powers of the head of state. Thus, the Congress's predominance over the executive power remained assured until the moment when a King would be found. The decision implied that the constituent power of the Congress was, by definition, unbounded.

The debates illustrate how the Constitution immediately acquired a position of prominence that was both legal and symbolic: it became the one standard against which the legality of all actions of the constituted powers could be measured and it even served as a rule for the constituting powers. As a consequence, the categories 'constitutional' versus 'unconstitutional' gained importance in political debate. The question of constitutionality was especially important in the period between the Constitution's promulgation in February and the inauguration of King Leopold in July 1831. The competencies of the Congress and the government respectively were debated in terms of their constitutionality. Accusing political opponents of making unconstitutional proposals became an efficient tactic for delegitimizing these proposals.

The maintenance of the new Constitution was jealously guarded by public opinion and the press as well. For example, on 11 March 1831, the Courrier de la Sambre published an article entitled "A violation of the Constitution". The article signaled that a few days earlier a decision of the government had been countersigned, not by the responsible minister, but by a high-placed functionary. This did not conform to the constitutional rules on ministerial responsibility:

The Regent be warned that the most profound respect for our new fundamental law and a strict observation of this law are required of his position, and the position of the country. Every transgression will be fatal, and must immediately be signaled and repressed. ${ }^{150}$

\footnotetext{
148“'Votre constitution est prête, il faut la mettre en vigueur. Pour cela, il vous manque un roi. Aux termes de l'article 85 de la constitution, quand le trône est vacant, on pourvoit à l'administration du royaume par une régence". Huyttens (1844-1845), vol. 2, p. 567, 22/02/1831.

149، 'Admettre les propositions qui vous sont soumises serait inconstitutionnel, et je pense que vous ne voulez pas violer le pacte fondamental avant qu'il ne soit en vigueur". Huyttens (1844-1845), vol. 2, p. 567, 22/02/1831.

150، Que M. le Régent y prenne garde, le respect le plus profond pour notre nouvelle loi fondamentale, une observation stricte de cette loi, lui sont commandés par sa position et celle du pays; toute transgression serait fatale, et doit être instantanément signalée et réprimée". Courrier de la Sambre no. 291, 11/03/1831.
} 
Equally instructive is the debate over the acceptance of the peace treaty with the Netherlands on 1 July 1831, which was an essential condition for the consolidation of Belgian independence. The competency of the ministers with regard to this question was discussed in terms of their constitutional mandate. Drawing on a religious vocabulary, De Robaulx warned against what he called "constitutional heresies":

I hurry to respond to the observation of M. Duval, which is a constitutional heresy. (...) This matter involves touching the Constitution. Be warned that the Constitution is an arch of alliance; touch it and you will be struck death. Yes, you will be struck death by public opinion. $^{151}$

In the session of 12 April 1831, the question of whether legislative elections should be called was debated. It was argued that the Congress had reached the term of its mandate: since a Constitution had been drawn up and all the conditions for giving it its full execution were fulfilled, the constituent assembly should be dissolved. ${ }^{152}$ Isidore Fallon defended this argument, saying that the Congress's original mandate was limited to drawing up and promulgating a Constitution. After that it was obliged to resign. Otherwise, it committed an act of unconstitutionality and abuse of power:

In the present state of affairs, let us be careful. Because by reserving this competence for the Congress any longer (...), it may later be accused of unconstitutionality or usurpation of power. $^{153}$

\footnotetext{
151،JJe me hâte de répondre à l'observation de M. Duval, qui est une hérésie constitutionnelle. (...) C'est qu'il s'agit maintenant de toucher à la constitution. Prenez-y garde, la constitution, c'est une arche d'alliance; si vous y touchez, vous serez frappé de mort. Oui, vous serez frappé de mort par l'opinion". Huyttens (1844-1845), vol. 3, p. 369, 01/07/1831. This remark reflects the idea of the article 123 of the draft Constitution. Although it was finally not adopted, its spirit clearly remained: "The maintenance of the constitution and all the rights it consecrates are entrusted to the patriotism and the courage of the militia, the army, the magistrates and of all Belgians". Cf. Footnote 6.

${ }^{152}$ The Provisional Government decided to create the National Congress in its decree of 4 October 1830: "Un congrès national, où seront représentés tous les intérêts des provinces, sera convoqué. Il examinera le projet de constitution belge, le modifiera en ce qu'il jugera convenable, et le rendra, comme constitution définitive, exécutoire dans toute la Belgique". Bulletin des arrêtés et actes du Gouvernement Provisoire de la Belgique (1830), no. 4, p. 3. In the decree on the elections for the Congress of 10 October 1830, its task was defined as follows: "Considérant que le congrès appelé à décider des intérêts de la Belgique (...)". Bulletin des arrêtés et actes du Gouvernement Provisoire de la Belgique (1830), no. 7, p. 5.

153، Dans un pareil état de choses, prenons garde, en réservant plus longtemps au congrès cet acte important à la consolidation de notre indépendance et à l'affermissement de nos institutions, qu'on puisse un jour l'attaquer d'inconstitutionnalité ou d'usurpation de pouvoir'. Huyttens (18441845), vol. 3, p. $87,12 / 04 / 1831$.
} 
Fallon further insisted that the Regent should be able to exercise his functions in the way provided for by the Constitution, instead of being subjected to the will of the omnipotent Congress: "He must finally be able to govern by virtue of the Constitution and not by the will of the Congress alone". ${ }^{154}$

Nothomb protested that dissolving the Congress at that point in time would be the exact opposite of completing the mission with which it had been entrusted by the Nation. The great task of the Congress was to safeguard the gains of the Belgian Revolution and to consolidate them by establishing a stable state upon their base:

Our fellow citizens have invested us with complete social powers; they have consigned constituent power to us, they have charged us with the foundation of Belgian nationality; in short, they have entrusted the entire September Revolution to us. ${ }^{155}$

Given the pressing military, political and economic needs, these circumstances could not be said to have been attained: "Is Belgium's fate fixed because we have added one more Constitution to the long list of constitutions which the XIXth century has produced?". ${ }^{156}$

Unless the necessary conditions for the survival of the Constitution were fulfilled, all the Congress's efforts would have been in vain.

On 20 July 1831, one day before the inauguration of the King, the different modalities for the dissolution of the Congress were discussed one last time. Fallon proposed to definitely dissolve the Congress directly after the King's inaugural oath. Other members argued that the King should not be left in charge without a legislative assembly. Therefore they proposed to let Congress retain the legislative power until the election of the first regular Parliament, but to adjourn it in the meantime. Its constituent powers on the other hand would cease after the inaugural oath. Devaux and Nothomb proposed the latter option, but added that the Congress could only be convened on the King's initiative. ${ }^{157}$ Fallon objected that the King was exclusively bound by his oath on the Constitution, and that therefore the Congress was obliged to surrender its powers:

\footnotetext{
154“Il faut enfin qu'il puisse gouverner en vertu de la constitution, et non par la volonté seule du congrès". Huyttens (1844-1845), vol. 3, p. 88, 12/04/1831.

155“Nos concitoyens nous ont investis de la plénitude des pouvoirs sociaux; ils nous ont revêtus de la puissance constituante, ils nous ont dit de fonder la nationalité de la Belgique; ils nous ont, en un mot, confié la révolution tout entière de septembre". Huyttens (1844-1845), vol. 3, p. 87, 12/04/1831.

156، 'Le sort de la Belgique est-il fixé parce que nous avons ajouté une constitution à la longue liste des constitutions qu'a engendrées le XIXe siècle?". Huyttens (1844-1845), vol. 3, p. 87, $12 / 04 / 1831$.

157،LLe congrès national s'ajournera immédiatement après la prestation de serment du roi; il sera dissous de plein droit le jour de la réunion des chambres. Jusqu'à l'époque de cette dissolution, le roi seul aura le droit de convoquer le congrès, qui ne pourra plus exercer désormais que la partie du pouvoir législatif que la constitution attribue aux chambres”. Huyttens (1844-1845), vol. 3, p. 612, 20/07/1831.
} 
The only condition imposed on the King is the oath on the Constitution. Neither our constituent power nor our legislative power can subsist. The power of the Congress is a constitutional power. ${ }^{158}$

Beyts, in favor of dissolution, argued that it was unconstitutional to let a single Chamber exercise the legislative power. In the absence of an elected Parliament, a constitutional legislative power could not exist: "The King has no sanction in the presence of a single Chamber. He has sworn loyalty to the Constitution; let us also be loyal and leave". ${ }^{159}$ Forgeur likewise maintained that Nothomb and Devaux's proposal, which was finally approved by the assembly, was unconstitutional.

\section{Precedence in the Belgian Constitution}

We have seen how the idea of precedence in the Belgian Constitution was informed by the political opposition against the Dutch King in the years preceding the Belgian Revolution. The Belgian opposition called upon the Fundamental Law in an effort to legitimize its resistance to royal authoritarianism. When this tactic failed, it established a new legal order with a new Constitution at its base. The next question then, is how this precedence was laid out in the Constitution itself. The Belgian Constitution is exceptional in that it does not have a preamble, which would be the most logical place for statements on the status of the constitutional text in relation to ordinary law. ${ }^{160}$ Instead of being explicitly proclaimed, the precedence of the Constitution is expressed by several articles within the

\footnotetext{
158“'La seule condition imposée au roi, c'est le serment à la constitution: notre pouvoir constituant ni législatif ne peut subsister. Le pouvoir du congrès est un pouvoir constitutionnel”. Huyttens (1844-1845), vol. 3, p. 611, 20/07/1831.

159،"Le roi n'a pas de sanction avec une chambre unique. Il jure fidélité à la constitution; soyons-y également fidèles et allons-nous-en”. Huyttens (1844-1845), vol. 3, p. 611, 20/07/1831.

${ }^{160}$ In the session of 18 November 1830 , Boucqueau de Villeraie proposed to draw up a manifesto that would serve as a preamble to the Constitution. The manifesto was to contain a legitimation of the Belgian Revolution, as well as the decrees on Belgian independence and the deposition of William I. The proposal was adopted and a commission, composed of Trentesaux, Théophile Fallon, Charles-Hippolyte Vilain XIIII, Forgeur, Van Crombrugghe, Lecocq, De Ryckere, Count Vilain XIIII, De Gerlache and Boucqueau de Villerain was charged with the task. The commission never convened however. In the session of 13 April, the National Congress renewed its intention to draw up a manifesto containing "the grievances of the Belgian people". The commission was reshuffled but again failed to produce results. In the meantime, during the session of 24 February 1831, Devaux proposed to include the decrees of 18 and 24 November (on national independence and the exclusion of the Nassau dynasty from succession to the Belgian throne) in the Constitution. On Beyts's proposal, and with a view to preventing their later modification by constitutional revision, the decrees were not included into the Constitution however, but were granted constitutional status: "nous les rendons irrévocables; ils ne feront pas partie de la constitution, mais ils seront comme la base sur laquelle elle repose". The decision was published in the Bulletin Officiel on 24 February. A preamble was never drawn up. Bulletin Officiel des décrets du Congrès national de la Belgique et des arrêtés du pouvoir exécutif (1830-1831), vol. 3, no. XVI, p. 187, decree of
} 
constitutional text. Their tendency and formulation often bespeaks the influence of British constitutional law, as reformulated by Constant. We will list these articles and explain them by looking at the constituent debates and at constitutional manuals.

\subsection{Differentiation from Normal Legislation}

- The Constitution cannot be suspended.

Art. 130: The Constitution cannot be wholly or partially suspended. ${ }^{161}$

This article was not included in the draft of the Constitutional Commission. It was added during the Congress debate of 5 February 1831 upon the suggestion of Van Snick. Van Snick first proposed the following article, borrowed from Benjamin Constant:

The constitutional powers only exist by virtue of the Constitution. They cannot, in whichever case or under whichever pretext, suspend its action. ${ }^{162}$

He supported his suggestion by referring to the political and institutional instability of France, where every regime violated and suspended the constitutions of its predecessors, under the motto Salus populi suprema lex esto. Instead, Van Snick argued that the wellbeing of the people was "always attached to the inflexible execution of the laws, especially of the fundamental law". ${ }^{163}$ His proposal was meant precisely "to prevent such infractions, such suspensions and coups". 164

The proposal was approved, but a discussion developed over its formulation. De Robaulx considered prohibitive measures illusory, since constitutions could ipse facto only be violated by illegal means. ${ }^{165}$ The article was thereupon reformulated so as to better express its intention to prevent the constituted powers from

24 February 1831; Huyttens (1844-1845), vol. 1, pp. 180-182, 18/11/1830; p. 261 (23 November 1830); p. 388 (11 December 1830) and vol. 2, p. 586, 24/02/1831; pp. 94-97 (13 April 1831).

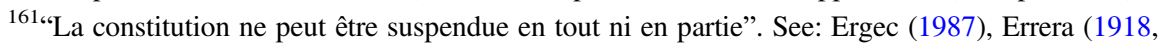
pp. 17-19), Huberlant (1982, pp. 337-338) and Van Drooghenbroeck (2006).

162،"Les pouvoirs constitutionnels n'existant que par la constitution, ils ne peuvent dans aucun cas, ni sous aucun prétexte, en suspendre l'action". Huyttens (1844-1845), vol. 2, p. 464, 05/02/1831. 163، "toujours attaché à l'inflexible exécution des lois, et surtout de la loi fondamentale".

164“'de prévenir ces infractions, ces suspensions et ces coups d'État”.

165،Une constitution ne peut être violée que par un coup d'État ou une révolution. Toute disposition prohibitive me paraît illusoire" (A constitution can only be violated by a coup or by a revolution. Prohibitive measures seem illusory to me). Huyttens (1844-1845), vol. 2, p. 464, $05 / 02 / 1831$. 
suspending the Constitution. Lebeau agreed, arguing that even the possibility of a violation needed to be precluded. ${ }^{166}$

- Constitutional revision is impossible during a regency.

Art. 84: No constitutional revision is admitted during a regency. ${ }^{167}$

The article was based on Art. 233 of the Fundamental Law. ${ }^{168}$ It was passed without discussion, with the clear intention of preventing constitutional change in times of crisis. ${ }^{169}$

- Special revision procedure.

Art. 131: The legislative power has the right to declare that there are reasons to revise such constitutional provision as it determines.

Following such a declaration, the two Houses are automatically dissolved.

Two new Houses are then convened, in accordance with Article 71.

These Houses make decisions, in common agreement with the King, on the points submitted for revision.

In this case, the Houses can only debate provided that at least two thirds of the members who make up each House are present; and no change is adopted unless it is supported by at least two thirds of the votes. ${ }^{170}$

The procedure for constitutional revision was rather rigid. ${ }^{171}$ New elections and a special majority were obligatory. Discussion on this article was limited and it was accepted without change. The only debate concerned the measure of flexibility of the procedure. Lebeau objected to the separate vote in both chambers, which would allow one chamber to block the revision wished for by the other. This he considered dangerous for the stability of the institutions. ${ }^{172}$

\footnotetext{
${ }^{166 ،}$ “Si la charte française avait contenu un semblable article, jamais les ministres de Charles $\mathrm{X}$ n'auraient pu trouver un prétexte pour suspendre la charte" (If the French Charte had contained a similar article, the ministers of Charles $\mathrm{X}$ would not have found a pretext for suspending the charter). Huyttens (1844-1845), vol. 2, p. 465, 05/02/1831.

167“'Aucun changement à la Constitution ne peut être fait pendant une régence".

${ }^{168}$ Descamps (1981, p. 45).

${ }^{169}$ Errera (1918, p. 22) and Thonissen (1879, p. 227).

${ }^{170 ،}$ "Le pouvoir législatif a le droit de déclarer qu'il y a lieu à la révision de telle disposition constitutionnelle qu'il désigne. Après cette déclaration, les deux chambres sont dissoutes de plein droit. Il en sera convoqué deux nouvelles, conformément à l'article 71. Ces chambres statuent, d'un commun accord avec le Roi, sur les points soumis à la révision. Dans ce cas, les chambres ne pourront délibérer si deux tiers au moins des membres qui composent chacune d'elles ne sont présents; et nul changement ne sera adopté s'il ne réunit au moins les deux tiers des suffrages".

${ }^{171}$ Errera (1918, pp. 20-22) and Thonissen (1879, pp. 338-340).

172،'S'il n'y a pas de moyen de faire des changements à la constitution, dès que l'opinion se sera prononcée contre elle, elle sera ou enfreinte, ou méprisée" (If there is no way to make changes to the Constitution, she will either be violated or despised, as soon as public opinion pronounces against her). Huyttens (1844-1845), vol. 2, p. 461, 4 February 1831.
} 
- Abolishment of all contrary previous legislation.

Art. 137: The Fundamental Law of 24 August 1815 and all the provincial and local statutes are abolished. ${ }^{173}$

Art. 138: From the day when the Constitution enters into force, all the laws, decrees, decisions, resolutions and other acts that contravene it, are abrogated. ${ }^{174}$

The second part of Art. 137 was based on the Fundamental Law of 1815, whereas Art. 138 was based on Art. 70 of the French Charter of $1830 .{ }^{175}$ Both were approved without motivation or debate. They are logical measures to establish precedence of the Constitution over all previous or contradictory legislation. ${ }^{176}$

\subsection{The Oath on the Constitution}

Art. 80: The King attains his majority upon his eighteenth birthday.

The King only accedes to the throne after having sworn the following oath before the united Houses: "I swear to observe the Constitution and the laws of the Belgian people, to preserve the country's national independence and its territorial integrity". 177

The article was based on Art. 38, 52 and 53 of the Fundamental Law. ${ }^{178}$ The oath on the Constitution was the prerequisite for the King to ascend to the throne. Between the death of the King and the inauguration of his successor, the powers of the head of state were exercised by the council of ministers in the name of the Belgian People and on their responsibility. The draft Constitution did not contain the oath: it followed that the royal power was directly inherited by his successor. This was changed by the National Congress. The Congressmen who insisted on the introduction of the oath and the public inauguration stressed the fact that the oath constituted a legal ground for deposing the monarch in case he violated the Constitution. ${ }^{179}$ This rule had existed under the Old Regime, as several members observed. References were made to the Old Regime clause of the ancient

\footnotetext{
173، La loi fondamentale du 24 août 1815 est abolie, ainsi que les statuts provinciaux et locaux. Cependant les autorités provinciales et locales conservent leurs attributions jusqu'à ce que la loi y ait autrement pourvu".

174“"A compter du jour où la Constitution sera exécutoire, toutes les lois, décrets, arrêtés, règlements et autres actes qui y sont contraires, sont abrogés".

${ }^{175}$ Descamps (1981, p. 41; 46).

${ }^{176}$ Errera (1918, p. 270) and Thonissen (1879, pp. 343-344).

177،LLe Roi est majeur à l'âge de dix-huit ans accomplis. Il ne prend possession du trône qu'après avoir solennellement prêté, dans le sein des chambres réunies, le serment suivant: 'Je jure d'observer la Constitution et les lois du peuple belge, de maintenir l'indépendance nationale et l'intégrité du territoire"'.

${ }^{178}$ Descamps (1989, 44-45).

${ }^{179}$ Huyttens (1844-1845), vol. 2, pp. 67-68, 09/01/1831; p. 487, 07/02/1831.
} 
constitution of the Duchy of Brabant which freed subjects of their loyalty to the prince when he did not respect his constitutional oath.

The discussion came about at the subject of the inviolability of the head of state. The formulation proposed by the Constitutional Commission seemed to suggest that the King could not in any way be deposed. The formulation of Art. 39 on the inviolability of the head of state was therefore adapted into "The King's person is inviolable; his ministers are accountable", which included the possibility of deposition. ${ }^{180}$ Destouvelles proposed copying the oath of the ancient constitution of Brabant which released the subjects of their fidelity to the prince in case he violated the Constitution. ${ }^{181}$ Beyts followed the same reasoning when proclaiming that he did not want "a king without a contract": "I can hardly agree to the principle allowed in France: the King is dead, long live the King! I will not cry 'Long live the King' if he has not sworn the oath". ${ }^{18}$

In other words, the oath turned the Constitution into the measure for the legality of the king's every action. Apart from the oath, the Old Regime inauguration ceremony in the presence of the assembled people was revived. ${ }^{183}$ The goal was to make the oath on the Constitution "more sacramental". In addition, the Congress introduced an oath to the Constitution for all members of Parliament, magistrates, army officers and civil servants. ${ }^{184}$ These oaths were prescribed by decree however and not included in the Constitution. ${ }^{185}$ Interestingly, the members of Parliament only swore to the Constitution, whereas the others also needed to swear loyalty to the laws and the King. This resulted from the fact that the Constitution was the only limit on the legislative power of Parliament, which neither the laws nor the King could bind.

\subsection{Judicial Review}

There is no mention of judicial review in the Constitution, nor in the debates of the National Congress. However, Art. 28 and 107 offer indications as to the opinion of the Congress in this matter. Art. 28 states that only the legislative power may decide the interpretation of the law, or in other words the référé législatif: "Only the

\footnotetext{
180“La personne du chef de l'État est inviolable; ses ministres sont responsables". Huyttens (18441845), vol. 2, 09/01/1831.

${ }^{181}$ Huyttens (1844-1845), vol. 2, pp. 67-68, 09/01/1831.

182،"Je n'admets guère (...) le principe admis en France: Le roi est mort, vive le roi! Je ne crie pas, Vive le roi, s'il n'a pas juré”. Huyttens (1844-1845), vol. 2, p. 487, 07/02/1831. On the absence of this principle in the Belgian Constitution: Errera (1918, p. 199).

${ }^{183}$ On these references, see: Deseure (2016b), Dubois (2005b, pp. 238-241), Dumont (1981) and De Lichtervelde (1930, p. 13).

${ }^{184}$ Huyttens (1844-1845), vol. 3, pp. 608-609, 20/07/1831.

${ }^{185}$ Errera (1918, p. 323).
} 
legislative power can give an authoritative interpretation of the laws". ${ }^{186}$ The context of this stipulation is the following:

The law can only have been intended in one sense by the legislator; the other senses that one wishes to attribute to it are by necessity wrong.

When the Court of Cassation and the other courts and tribunals are divided about the sense of the law, the intervention of the legislative power is necessary ${ }^{187}$

Art. 107 states that the tribunals may only apply decisions of the executive power when they conform to the law. However, they do not have the power to annul or invalidate these decisions: "The courts and tribunals only apply the general, provincial and local decisions and rulings to the extent that they conform to the law". ${ }^{188}$

These articles do not refer to the question of the conformity of the law to the Constitution but they do make clear that the judicial power is not entitled to interfere in the spheres of action of the legislative and executive powers. It has been supposed by analogy that tribunals do not have the competence of judicial review. ${ }^{189}$ This is a logical outcome of the importance attached to the separation of powers in the Belgian Constitution. ${ }^{190}$ Judicial review would contradict Art. 26 which states that the legislative power is exercised by the Chambers and the King collectively. This is a classical argument against the establishment of Constitutional Courts (cf. debates on the American Supreme Court). In the Belgian context the lawgiver is protected against interference of the judiciary.

Given that Parliament cannot be forced to respect the Constitution, it has unrestricted legislative power. ${ }^{191}$ In other words, it has the power to make unconstitutional law. However, the Congress clearly expected future parliaments to act in accordance with the Constitution. The Congressmen believed that the respect of succeeding assemblies for the Constitution would be too great to ever allow the introduction of unconstitutional laws. ${ }^{192}$ In addition, the oath for members of Parliament on the Constitution, as well as part 2 of Art. 25 ("All the powers

\footnotetext{
186، 'L'interprétation des lois par voie d'autorité n'appartient qu'au pouvoir législatif'. For a discussion of this article: Neut (1842, p. 161).

187،La loi ne peut avoir qu'un seul sens dans l'intention du législateur; les autres sens qu'on veut lui attribuer sont nécessairement faux"; "Lorsque la cour de cassation et les autres cours et tribunaux sont divisés sur le sens de la loi, l'intervention du pouvoir législatif est nécessaire". Report of the Central Section, by Jean-Joseph Raikem, on the judicial power. Huyttens (18441845), vol. 4, p. 96.

188،Les cours et tribunaux n'appliqueront les arrêtés et règlements généraux, provinciaux et locaux, qu'autant qu'ils seront conformes aux lois”. Le Jeune (1857) and Van den Steene (1963, p. 55) and Warlomont (1929).

${ }^{189}$ Thonissen (1879, p. 133).

${ }^{190}$ See De Maeyer (1994, p. 51), for the discussion between Eugène Verhaegen and Charles Faider on the question of unconstitutional laws.

${ }^{191}$ Errera (1918, p. 270) and Stengers (1949, p. 681).

${ }^{192}$ For the same reason, Charles Faider, one of the most prominent Belgian lawyers of the nineteenth century, thought the introduction of judicial review was useless. Stengers (1949, p. 692).
} 
emanate from the nation. They are exercised in the manner established by the Constitution") did constitute a legal restraint of sorts on the power of the legislative branch. ${ }^{193}$ As we have seen, as soon as the Constitution was promulgated, 'constitutionality' became an important argument in the debates over new legislation.

\section{Epilogue: Constitutional Discourse After 1831}

The history of the Constitution after 1831 illustrates that it effectively functioned as the single, fundamental law binding the legal and political order. Only in 191483 years after its promulgation - was the first unconstitutional law passed by the Belgian lawgiver. ${ }^{194}$ Moreover, the Constitution proved to be stable: only twice in the nineteenth century was the procedure for constitutional revision used, both times mainly in order to adapt the suffrage conditions to social reality. ${ }^{195}$ Revisions affecting the foundations of the state only followed after WWII.

The resilience of the Constitution can at least partly be explained by the symbolic prestige it enjoyed. Both in the Congress and in the press the new Constitution was heralded as Belgium's ultimate guarantee of liberty. It was presented as the foundation of the new state and the guarantor of the wellbeing of its inhabitants. A typical example appeared in the newspaper Courrier de la Sambre:

Our beautiful Constitution, masterpiece of our worthy representatives, will be respected, it will be the sacred arch that will remain as an eternal monument to our courage and to the energy with which we have shaken off a degrading yoke. ${ }^{196}$

Constitutionality (as opposed to unconstitutionality) and respect for the Constitution remained important legitimizing categories in Belgian political discourse throughout the nineteenth century.

The ruling classes actively promoted respect for the Constitution by the establishment of a popular cult, including monuments and hymns. In the words of Congressman Beyts, the Constitution was in effect sacralized. ${ }^{197}$ Although this quasi-sacred reverence for the Constitution existed from the very beginning, it gained strength especially after the revolutionary wave of 1848 . During the first two decades after the Revolution, public state celebrations focused more on the martial side of the revolutionary events, with the memory of the fallen heroes of the 'September Days' of 1830 as the centerpiece. ${ }^{198}$ In the year 1848 the focus shifted.

\footnotetext{
${ }^{193}$ Errera (1918, p. 270).

${ }^{194}$ Stengers (1949, p. 694).

${ }^{195}$ Gilissen (1958, p. 18).

196“Notre belle constitution, chef-d'œuvre de nos dignes représentans, sera respectée, ce sera l'arche sainte qui restera comme un monument éternel de notre courage et de l'énergie avec laquelle nous avons su secouer un joug avilissant". Courrier de la Sambre no. 406, 24/07/1831. ${ }^{197}$ Huyttens (1844-1845), vol. 2, p. 487, 07/02/1831.

${ }^{198}$ Huygebaert (2013, p. 154) and Janssens (2001, p. 52).
} 
The introduction of a few liberal measures prevented an outbreak of revolution: the franchise was widened by lowering the suffrage requirements to the constitutional minimum, and public service was made incompatible with a parliamentary mandate so that the Parliament grew more independent from the government. The measures succeeded in quelling the modest revolutionary unrest in Belgium. ${ }^{199}$ As a resultand partly under the influence of better relations with Holland-the government turned to celebrating the stability of the country's institutions rather than the revolutionary feats of 1830 .

The Constitution was hailed as the unshakeable foundation of the state, which, due to its liberal character and just repartition of power, had averted the danger of insurrection. $^{200}$ The Constitution thus grew into the symbolic alpha and omega of the Belgian state system. The culmination of the constitutional cult was the creation of the Congress Column monument in 1850. The Column, a grandiose monument designed by the architect Joseph Poelaert, commemorated the founding of the Belgian state and the creation of the Belgian Constitution by the National Congress in 1831. The major dates of the Belgian Revolution, the names of the members of the Congress and the Provisional Government, and key passages from the Belgian Constitution were inscribed on its pedestal. On the four corners of the pedestal sat gigantic bronze statues of the four 'cardinal liberties' proclaimed in the second title of the Constitution. ${ }^{201}$

This chapter has shown that constitutional precedence was not projected on the Constitution post factum. The idea was tightly bound up with the genesis of the Belgian Constitution itself, and at least partly resulted from the political theory developed by the Belgian opposition against the rule of the Dutch King. The debates over sovereignty and accountability of the government were waged in constitutional terms by both the opposition and the government, but resulted in completely opposite interpretations. The Belgian Constitutional Assembly was careful to prevent a repetition of this debate by combining the idea of constitutional precedence with a desire for clarity: royal inviolability and ministerial responsibility were spelled out in the Constitution, while sovereignty was safely vested in the Nation. ${ }^{202}$ Above all, they ensured that the Constitution acted as the basic rule of the legal and political order. As the expression of the will of the sovereign Nation, it excluded every other claim to power. Thus, the ambiguity, typical of Restoration

\footnotetext{
${ }^{199}$ The population stayed calm, while the only attempt at armed attack on the system - the invasions of the country from France by an improvised battalion of a few hundred revolutionariesgloriously failed. Witte (2006).

${ }^{200}$ Huygebaert (2015).

${ }^{201}$ The $47 \mathrm{~m}$ high column was originally to be crowned by a representation of the Constitution, until Parliament decided upon a statue of King Leopold instead.

${ }^{202}$ Remarkably, the political responsibility of ministers to Parliament (as opposed to the juridical responsibility) was not made explicit in the Constitution, despite being clearly intended by the National Congress. The political responsibility only developed as a result of political practice in the first years after independence. Deseure (2016a, p. 125), Ganshof Van der Meersch (1950, p. 183), Harsin (1937, p. 166) and Müßig (2011, p. 499).
} 
constitutionalism, between national sovereignty on the one hand and monarchical sovereignty on the other, was overcome. This idea was expressed by the inaugural oath, which unequivocally sealed the terms of the social contract, as well as by a series of measures aimed at guaranteeing both the precedence and the endurance of the Constitution.

\section{Summary (Dutch): Grondwettelijke Voorrang en het Ontstaan van de Belgische Grondwet van 1831}

Het idee van grondwettelijke voorrang is een kernidee van het moderne grondwetsbegrip. Het wordt hier gedefinieerd als het vastleggen van de politieke en wettelijke orde in een uniforme, positiefrechtelijke tekst die het karakter heeft van een wettelijke bindende, voorafgaande rechtsnorm. Dit hoofdstuk onderzoekt de manier waarop het concept van grondwettelijke voorrang werd verankerd in de Belgische grondwet van 1831. Het doet dit vanuit het standpunt van de genese van de grondwet in de context van de Belgische Revolutie. Een historisch-genealogische benadering wordt daarbij gecombineerd met een juridische.

Het eerste deel gaat in op het ontstaan van de Belgische grondwet in oppositie met de Fundamentele Wet, de grondwet van het Koninkrijk der Verenigde Nederlanden. Het laat zien dat het verzet van de Belgische oppositie tegen het beleid van de regering van koning Willem I tot een debat leidde over de interpretatie en het karakter van de Fundamentele Wet. Zowel de overheid als de oppositie beriepen zich op de grondwet om hun respectievelijke claims te legitimeren, maar ontwikkelden daarbij een volstrekt tegengestelde interpretatie ervan. De overheid onderstreepte de rol van het monarchale macht in het staatsbestel via een letterlijke lezing van de grondwet, in combinatie met het idee van voorafgaande monarchale soevereiniteit. De oppositie daarentegen, geïnspireerd door de constitutionele theorie van Benjamin Constant, beriep zich op de geest van de grondwet in een poging om de koninklijke macht aan banden te leggen. Deze tweestrijd beïnvloedde vervolgens de opvatting van grondwettelijke voorrang zoals die tot uiting kwam in de debatten van de Belgische constituante.

Het discours van de Belgische oppositie over de Fundamentele Wet onderging een transformatie op het moment dat het verzet tegen de Nederlandse overheid uitmondde in revolutie. De revolutionairen legitimeerden het breken met de wettelijke orde door een beroep op de rechten van de Belgische Natie, die de Fundamentele Wet in haar ogen niet voldoende wist te garanderen tegen koninklijk despotisme. Het idee van grondwettelijke voorrang bleef evenwel intact en vond vervolgens zijn neerslag in de nieuwe Belgische grondwet. Dit blijkt uit de debatten in het Nationaal Congres en in de pers. Grondwettelijkheid werd, vanaf de goedkeuring van de grondwet op 7 februari 1831, een belangrijke categorie om het optreden van de constituerende en geconstitueerde machten mee te beoordelen. 
Het tweede deel onderzoekt de manier waarop grondwettelijke voorrang werd verankerd in de grondwetstekst zelf. Bij gebrek aan preambule wordt het speciale karakter van de gronwetstekst niet explicitiet uitgedrukt. Wel komt het idee tot uiting in een reeks grondwetsartikelen die betrekking hebben op (a) de bijzondere status van het grondwettelijk recht ten opzichte van gewone wetgeving (onder meer in de modaliteiten voor grondwetswijziging) en (b) de status van de grondwet als wettelijk bindende norm voor het optreden van de geconstitueerde machten (onder meer via de grondwettelijke eed van de monarch).

Tot slot werd de grondwettelijke voorrang ook symbolisch uitgedrukt door middel van een semi-religieus discours waarin de grondwet werd voorgesteld als de stichtingsakte van de staat en de ultieme garantie voor haar toekomstige welzijn. $\mathrm{Na}$ 1848 culmineerde dit discours zelfs in een volwaardige grondwetscultus.

\section{Summary (French): La Primauté de La Constitution et La Genèse de La Constitution Belge de 1831}

La conception moderne de Constitution est fondée sur sa primauté. La primauté de la Constitution est ici définie comme l'établissement d'un ordre politique et légal au moyen d'un texte uniforme de droit positif véhiculant une norme prioritaire et juridiquement contraignante. Ce chapitre étudie la manière dont le concept de la primauté de la Constitution a été ancré dans la Constitution belge de 1831. Pour ce faire, il suivre une approche tant historique et «généalogique» que juridique.

La première partie est consacrée à la genèse de la Constitution belge en opposition avec la Loi Fondamentale du Royaume des Pays-Bas Unis. Elle montre comment l'opposition belge, en résistance envers le gouvernement du Roi Guillaume Ier, a ouvert un débat sur l'interprétation et le caractère de cette Loi Fondamentale. Tant le gouvernement que l'opposition se référaient à la Constitution pour légitimer leurs points de vue respectifs, mais en l'interprétant de manière contradictoire. Le gouvernement soulignait le rôle du Roi dans le fonctionnement de l'Etat, en appelant à une lecture littérale de la Constitution et à l'idée d'une souveraineté monarchique préalable. L'opposition, quant à elle, inspirée par la théorie constitutionnelle de Benjamin Constant, se référait au contraire à l'esprit de la Constitution dans le but de limiter le pouvoir royal. Ce conflit a eu une profonde influence sur la manière dont l'idée de la primauté de Constitution a été envisagée au sein de la constituante belge.

Le discours de l'opposition belge sur la Loi Fondamentale s'est fortement transformé au moment où la résistance contre le gouvernement néerlandais a pris le caractère d'une révolution. La rupture des révolutionnaires avec l'ordre légal se légitimait par la nécessité de protéger les droits de la Nation belge, que la Loi Fondamentale ne parvenait pas, à leurs yeux, à protéger suffisamment contre le despotisme royal. L'idée de la primauté de la Constitution restait néanmoins intacte et se retrouvait dans la toute nouvelle Constitution belge. Les débats menés au 
Congrès National et dans la presse en témoignent. À partir de l'approbation de la Constitution le 7 février 1831, le concept de 'constitutionalité' devient un élément important d'appréciation du comportement des pouvoirs constituants et constitués.

La deuxième partie est dédiée à la manière dont la primauté de la Constitution est inscrite dans le texte lui-même. En l'absence de préambule, le caractère spécial de la Constitution n'est pas exprimé de manière explicite. Par contre, il est mis en avant dans une série d'articles qui traitent (a) de la particularité du droit constitutionnel par rapport à la législation ordinaire (entre autres via les modalités de la révision de la Constitution) et (b) du statut de la Constitution comme norme emportant une contrainte juridique pour l'action des pouvoirs constitués (entre autre via le serment constitutionnel du monarque).

Enfin, la primauté de la Constitution est exprimée de manière symbolique au moyen d'un discours semi-religieux représentant la Constitution comme le document fondateur de l'Etat belge et comme la garantie ultime de son bien-être futur. Discours qui, après 1848 , culmine dans un culte constitutionnel à part entière.

\section{References}

Aerts R (2006) Een andere geschiedenis. Een beschouwing over de scheiding van 1830. In: Rietbergen P, Verschaffel T (eds) De erfenis van 1830. Acco, Leuven, pp 15-33

Aerts R (2016) Het ingesleten pad over de betekenis van de grondwet van 1815. In: Alen A, Heringa AW, Heirbaut D, Rotteveel Mansveld CJ (eds) De Grondwet van het Verenigd Koninkrijk der Nederlanden van 1815. Boom Juridisch, The Hague, Die Keure, Bruges, pp 1544

[Asser C] (1828) De la responsabilité ministérielle d'après le droit public du Royaume des Pays-Bas. Brest Van Kampen, Brussels

Blok PJ (1914) Maanen, Cornelis Felix van. In: Blok PJ, Molhuysen PC (eds) Nieuw Nederlandsch biografisch woordenboek, vol 3. A.W. Sijthoff, Leiden, pp 803-805

Bos EC (2009) Soevereiniteit en religie. Godsdienstvrijheid onder de eerste Oranjevorsten. Verloren, Hilversum

Breukelman JB (1912) Gijsbert Karel van Hogendorp. In: Blok PJ, Molhuysen PC (eds) Nieuw Nederlandsch biografisch woordenboek, vol 2. A.W. Sijthoff, Leiden, pp 588-593

[Brown H, Lagye V] (1852) Constitution de la Belgique. Edition illustrée. Delevingne et Callewaert, Brussels

Bulletin des arrêtés et actes du Gouvernement Provisoire de la Belgique (1830) Weissenbruch, Brussels

Bulletin Officiel des décrets du Congrès national de la Belgique et des arrêtés du pouvoir exécutif (1830-1831) Weissenbruch, Brussels

Castiau A (1829a) De la responsabilité, de la mise en accusation et du jugement des ministres en Belgique. Vander Schelden, Ghent

Castiau A (1829b) Réfutation du discours de M. le Baron Goubau sur la responsabilité ministérielle, suivi d'une réponse au National. Tarlier, Brussels

Colenbrander HT (1908) Ontstaan der grondwet: bronnenverzameling. Nijhoff, The Hague

De Gerlache E (1859) Histoire du Royaume des Pays-Bas depuis 1814 jusqu'en 1830. Goemaere, Brussels

De Lichtervelde L (1930) Introduction. In: du Bus de Warnaffe C, Beyaert C (eds) Le Congrès National. Biographies des membres du Congrès National et du Gouvernement Provisoire, 1830-1831. Librairie nationale d'art et d'histoire, Brussels, Paris 
De Maeyer J (1994) Arthur Verhaegen, 1847-1917. De rode baron. Leuven University Press, Leuven

Delbecke B (2012) De lange schaduw van de grondwetgever: perswetgeving en persmisdrijven in België (1831-1914). Academia Press, Ghent

Demoulin R (1989) Le courant libéral à l'époque de royaume des Pays-Bas et dans la Révolution de 1830. In: Verhulst A, Hasquin H (eds) Le libéralisme en Belgique. Deux cents ans d'histoire., 29-38. Brussels: Delta

Descamps E (1981) La mosaïque constitutionnelle. Essai sur les sources du texte de la Constitution belge. Peeters, Leuven

Deseure B (2016a) National sovereignty in the Belgian constitution of 1831. On the meaning(s) of article 25. In: Müßig U (ed) Reconsidering Constitutional Formation I National Sovereignty. A Comparative Analysis of the Juridification by Constitution. Springer, Berlin, pp 93-157

Deseure B (2016b) From Pragmatic Conservatism to Formal Continuity. Nineteenth-century Views on the Old Regime Origins of the Belgian Constitution. J Const Hist 32(2):257-277

Discailles E (1907) Rogier (Charles-Latour). In: Biographie nationale, vol 19. Académie Royale des Sciences, des Lettres et des Beaux-Arts de Belgique, Brussels, pp 693-781

Dubois S (2005a) Introduction. In: Dubois S, Janssens J, Minke A (eds) La Belgique en scène. Symboles, rituels, mythes (1830-2005). Archives générales du Royaume, Brussels, pp 9-11

Dubois S (2005b) L'invention de la Belgique: genèse d'un état-nation, 1648-1830. Racine, Brussels

Dumont GH (1981) Le serment de 21 juillet 1831: aboutissement et point de départ. In: Nous, Roi des Belges. 150 ans de monarchie constitutionnelle. Crédit Communal, Brussels, pp 25-34

Ergec R (1987) L'État de nécessité en droit constitutionnel belge. In: Le nouveau droit constitutionnel. Rapports belges au IIe Congrès mondial de droit constitutionnel. Bruylant, Brussels, pp 143-171

Errera P (1918) Traité du droit public belge. Giard \& Brière, Paris

Freson A (1932) Tielemans, Jean-François. In: Biographie nationale, vol 25. Académie Royale des Sciences, des Lettres et des Beaux-Arts de Belgique, Brussels, pp 246-250

Ganshof Van der Meersch W (1950) Des rapports entre le Chef de l'Etat et le gouvernement en droit constitutionnel belge. Revue de droit international et de droit comparé, special issue: 181197

Gilissen J (1958) Le régime représentatif en Belgique depuis 1790. La renaissance du livre, Brussels

Gilissen J (1967) Die belgische Verfassung von 1831. Ihr Ursprung und ihr Einfluss. In: Conze W (ed) Beiträge zur deutschen und belgischen Verfassungsgeschichte im 19. Jahrhundert. Klett, Stuttgart, pp 38-69

Goubau-d'Hovorst M (1829) Discours du Baron Goubau-d'Hovorst prononcé à la Première Chambre des Etats-Généraux, le 16 mai 1829, dans la discussion sur l'adresse à Sa Majesté, relativement aux pétitions présentées à la Seconde Chambre. Brest Van Kempen, Brussels

Harsin P (1930) Essai sur l'opinion publique en Belgique de 1815 à 1830. La Terre Wallonne, Charleroi

Harsin P (1937) La constitution belge de 1831 et la responsabilité ministérielle. Rev Hist Polit Const 1(1):164-177

Huberlant C (1982) État de siège et légalité d'exception en Belgique. In: Licéité en droit positif et références légales aux valeurs. Contribution à l'étude juridique du règlement des conflits de valeurs en droit pénal, public et international. Bruylant, Brussels, pp 381-431

Huygebaert S (2013) Les quatres libertés cardinales. De iconologie van pers, onderwijs, vereniging en geloof in België, als uitdrukking van een populariserende grondwetscultus vanaf 1848. Pro Memorie 15:154-180

Huygebaert S (2015) Unshakeable foundations. An iconological study of the Belgian constitutional cult following the 1848 revolution. J Belg Hist 45(4):11-39

Huyttens E (1844-1845) Discussions du Congrès National de Belgique, 1830-1831. Wahlen, Brussels 
Janssens J (2001) De Belgische natie viert. De Belgische nationale feesten, 1830-1914. Universitaire Pers Leuven, Leuven

Janssens J (2005) Les fêtes de l'état belge. In: Dubois S, Janssens J, Minke A (eds) La Belgique en scène. Symboles, rituels, mythes (1830-2005). Archives générales du Royaume, Brussels, pp 55-68

Juste T (1874) Louis de Potter, membre du gouvernement provisoire, d'après des documents inédits. Muquardt, Brussels

Kirsch M (1999) Monarch und Parlament im 19. Jahrhundert: der monarchische Konstitutionalismus als europäischer Verfassungstyp-Frankreich im Vergleich. Vandenhoeck und Ruprecht, Göttingen

Koch J (2013) Koning Willem I, 1772-1843. Boom, Amsterdam

Koch J (2015) Le Roi décide seul/de Koning alleen besluit. Het 'systeem Willem I'. In: Aerts R, Deneckere G (eds) Het (on)Verenigd Koninkrijk, 1815-1830 > 2015. Een politiek experiment in de Lange Landen. Ons Erfdeel, Rekkem, pp 49-58

Le Jeune J (1857) Du droit des tribunaux de vérifier la légalité des actes administratifs. Librairie polytechnique, Brussel

Le Roy A (1897). Meenen, Pierre-François Van. In: Biographie nationale, vol 14. Académie des Sciences, des Lettres et des Beaux-Arts de Belgique, Brussels, pp 233-250

Lebeau J (1830) Observations sur le pouvoir royal ou examen de quelques questions relatives aux droits de la couronne dans les Pays Bas. C. Lebeau-Ouwerx, Liège

Lok M (2011) De cultuur van het vergeten onder Willem I. In: Vosters R, Weijermars J (eds) Taal, natievorming en cultuurbeleid onder Willem I. Brussels: Koninklijke Vlaamse Academie van België voor Wetenschappen, Letteren en Schone Kunsten, pp 61-86

Magits M (1977) De Volksraad en de opstelling van de Belgische grondwet. Unpublished dissertation, Vrije Universiteit Brussel

Marteel S (2006) Van "oude constitutie" tot liberale grondwet. Het Belgische politieke natiebesef tussen 1815 en 1830. In: Rietbergen P, Verschaffel T (eds) De erfenis van 1830. Acco, Leuven, pp 35-52

Marteel S (2009) Inventing the Belgian revolution. Politics and political thought in the United Kingdom of the Netherlands (1814-1830). Unpublished dissertation, European University Institute Florence

Marteel S (2012) Polemieken over natievorming in het Verenigd Koninkrijk der Nederlanden. Een blik op de intellectuele wortels van het Belgisch nationalisme. In: Vosters R, Weijermars J (eds) Taal, natievorming en cultuurbeleid onder Willem I. Koninklijke Vlaamse Academie van België voor Wetenschappen, Letteren en Schone Kunsten, Brussels, pp 35-60

Mirkine-Guetzévitch B (1831) 1830 dans l'histoire constitutionnelle de l'Europe. Rev Hist Mod 34:241-256

Müßig U (2011) L'ouverture du mouvement constitutionnel après 1830: à la recherche d'un équilibre entre la souveraineté monarchique et la souveraineté populaire. Tijdschrift voor Rechtsgeschiedenis 79:489-519

Müßig U (2013) Montesquieu's mixed monarchy model and the indecisiveness of the 19th century European constitutionalism between monarchical and popular sovereignty. Historia et jus 3

Neut A (1842) La Constitution belge expliquée par les Congrès National, les Chambres et la Cour de Cassation, ou compte-rendu des débats qui ont eu lieu sur cette loi suprême. Annoot-Braeckmann, Ghent

[Olivier Schilperoort T] (1828) Quelques observations fondées sur les termes exprès de la Loi Fondamentale, à l'occasion de la Critique du Discours du Trône publiée dans le journal intitulé Le Courrier des Pays-Bas. Brest Van Kampen, Brussels

Philippart S (1984) Adelson Castiau, un bourgeois socialiste au XIXe siècle (1804-1879). In: Publications extraordinaires de la Société Royale d'Histoire et d'Archéologie de Tournai, vol 1. Tournai: Société Royale d'Histoire et d'Archéologie de Tournai, pp 157-176

Prutsch MJ (2013) Making sense of constitutional monarchism in post-Napoleonic France and Germany. Palgrave Mcmillan, New York 
Rotteveel Mansveld CJ, Velle K (2016) Inleiding. In: Alen A, Heringa AW, Heirbaut D, Rotteveel Mansveld CJ (eds) De Grondwet van het Verenigd Koninkrijk der Nederlanden van 1815. Boom Juridisch, The Hague, Die Keure, Bruges, pp 9-14

Slijkerman D (2011) Het geheim van de ministeriële verantwoordelijkheid. De verhouding tussen koning, kabinet, kamer en kiezer, 1848-1905. Bert Bakker, Amsterdam

Slijkerman D (2013) Wonderjaren. Gijsbert Karel Van Hogendorp, wegbereider van Nederland. Bert Bakker, Amsterdam

Stengers J (1949) Autour d'un centenaire. Les tribunaux belges et le contrôle de la constitutionnalité des lois. Rev Belge Philol Hist 27:679-701

Stourzh G (1977) Staatsformenlehre und Fundamentalgesetze in England und Nordamerika im 17. Und 18. Jahrhundert. In: Vierhaus $\mathrm{R}$ (ed) Herrschaftsverträge, Wahlkapitulationen, Fundamentalgesetze. Vandenhoeck und Ruprecht, Göttingen, pp 45-67

Tamse CA, Witte E (1992) Woord vooraf. In: Tamse CA, Witte E (eds) Staats- en natievorming in Willem I's koninkrijk (1815-1830). VUBpress, Brussels, pp 6-14

Tamse CA, Witte E (1992) Inleiding. In: Tamse CA, Witte E (eds) Staats- en natievorming in Willem I's koninkrijk (1815-1830). VUBpress, Brussels, pp 15-54

Thonissen JJ (1879) La Constitution belge annotée, offrant sous chaque article l'état de la doctrine de la jurisprudence et de la législation. Bruylant-Christophe, Brussels

Tielemans J-F (1829) Lettre à Monsieur Van Maanen, sur la responsabilité ministérielle. CochéMommens, Brussels

Van den Steene W (1963) De Belgische grondwetscommissie (oktober-november 1830): tekst van haar notulen en ontstaan van de Belgische grondwet. Brussels: Koninklijke Vlaamse Academie van België voor Wetenschappen, Letteren en Schone Kunsten

Van Drooghenbroeck S (2006) L'article 187 de la Constitution. Revue Belge de Droit 3:293-297

Van Kuyck J (1914) Asser (Carel). In: Blok PJ, Molhuysen PC (eds) Nieuw Nederlandsch biografisch woordenboek, vol 3. A.W. Sijthoff, Leiden, pp 42-44

Van Sas N (1992) Het Grote Nederland van Willem I: een schone slaapster die niet wakker wilde worden. In: Tamse CA, Witte E (eds) Staats- en natievorming in Willem I's koninkrijk (18151830). VUBpress, Brussels, pp 171-185

Van Sas N (2004a) Het politiek bestel onder koning Willem I. In: van Sas N (ed) De metamorfose van Nederland. Amsterdam University Press, Amsterdam, pp 413-435

Van Sas N (2004b) Onder waarborging eener wijze constitutie. Grondwet en politiek, 1813-1848. In: van Sas N (ed) De metamorfose van Nederland. Amsterdam University Press, Amsterdam, pp 459-480

Van Velzen P (2005) De ongekende ministeriële verantwoordelijkheid. Theorie en praktijk, 18131840. Wolf Legal Publishers, Nijmegen

Van Velzen P (2015) De invloed van de theorie van Benjamin Constant op het regime van koning Willem I. In: De Hert P, Kinneging A, Colette M (eds) Benjamin Constant. Ontdekker van de moderne vrijheid. Pelckmans, Kalmthout, pp 119-160

Van Zanten J (2004) Schielijk, winzucht, zwaarhoofd en bedaard. Politieke discussie en oppositievorming, 1813-1840. Wereldbibliotheek, Amsterdam

Varenbergh E (1884-1885) Goubau-d'Hoogvoorst (Melchior-Joseph-François, baron). In: Biographie nationale, vol 8. Académie Royale des Sciences, des Lettres et des Beaux-Arts de Belgique, Brussels, p 159

Velema W (1998) Revolutie, Republiek en Constitutie. De ideologische context van de eerste Nederlandse Grondwet. In: van Sas N, te Velde H (eds) De eeuw van de grondwet. Grondwet en politiek in Nederland, 1787-1917. Kluwer, Deventer, pp 20-44

Vermeersch AJ (1992) Willem I en de pers in de Zuidelijke Nederlanden, 1814-1830. In: Tamse CA, Witte E (eds) Staats- en natievorming in Willem I's koninkrijk (1815-1830). VUBpress, Brussels, pp 310-321 
Vilain XIIII CH (1830) Appel au Congrès, par un ami de la patrie. Vanryckegem-Hovaere, Ghent

Warlomont R (1929) Le pouvoir judiciaire et la fonction législative dans l'histoire du droit public belge. La Belgique judiciaire, col. 602-616

Wils L (2009) Van de Belgische naar de Vlaamse natie. Een geschiedenis van de Vlaamse Beweging. Acco, Leuven

Witte E (1979) De Belgische radicalen: brugfiguren in de democratische beweging (1830-1850). Tijdschrift voor Geschiedenis 1:11-45

Witte E (2006) De constructie van België, 1828-1847. Lannoo Campus, Leuven

Witte E (2010) De doorbraak van een burgerlijke parlementair-constitutionele staat (1830-1848). In: Witte E, Craeyneckx J, Meynen A (eds) Politieke geschiedenis van België. Standaard Uitgeverij, Antwerp, pp 57-61

Witte E (2016) De Grondwet van het Verenigd Koninkrijk der Nederlanden (1815) en het ontstaan van de Belgische Constitutie (1831). In: Alen A, Heringa AW, Heirbaut D, Rotteveel Mansveld CJ (eds) De Grondwet van het Verenigd Koninkrijk der Nederlanden van 1815. Boom Juridisch, The Hague, Die Keure, Bruges, pp 15-44

Worst IJH (1992) Koning Willem I. Het begin van 'ons grondwettig volksbestaan'. In: Tamse CA, Witte E (eds) Staats- en natievorming in Willem I's koninkrijk (1815-1830). VUBpress, Brussels, pp 56-75

Wouters H (1958) De Brusselse radikale pers in de eerste roes van de onafhanklijkheid (18301844). In: Vermeersch AJ, Wouters H (eds) Bijdragen tot de geschiedenis van de Belgische pers. Nauwelaerts, Leuven, Paris, pp 139-153

Zuidema E (1921) Olivier Schilperoort (Tielman). In: Blok, PJ, Molhuysen PC, Knappert L (eds) Nieuw Nederlandsch biografisch woordenboek, vol 5, Leiden: A.W. Sijthoff, pp 396-397

Open Access This chapter is licensed under the terms of the Creative Commons Attribution 4.0 International License (http://creativecommons.org/licenses/by/4.0/), which permits use, sharing, adaptation, distribution and reproduction in any medium or format, as long as you give appropriate credit to the original author(s) and the source, provide a link to the Creative Commons license and indicate if changes were made.

The images or other third party material in this chapter are included in the chapter's Creative Commons license, unless indicated otherwise in a credit line to the material. If material is not included in the chapter's Creative Commons license and your intended use is not permitted by statutory regulation or exceeds the permitted use, you will need to obtain permission directly from the copyright holder. 